\title{
The Use of Arabic (L1) in the EFL Classrooms: How Do Umm Al-Quwain Teachers and Students Perceive It?
}

\author{
Mohammed Hamid Al-Ta'ani \\ Correspondence: Mohammed Hamid Al-Ta'ani, Assistant Professor, Department of English Language and Translation, \\ Emirates Canadian University College (ECUC), Umm Al-Quwain, United Arab Emirates.
}

Received: March 4, 2019

doi:10.11114/ijce.v2i2.4229

\author{
Accepted: April 1, $2019 \quad$ Online Published: April 23, 2019
}

URL: https://doi.org/10.11114/ijce.v2i2.4229

\begin{abstract}
The role of students' native language (L1) in the second language (L2) classrooms has been a debatable issue for a long time in the field of English Language teaching as a foreign language (EFL). The present study which took place in the United Arab Emirate (UAE), more specifically, at Umm Al-Quwain Educational Zone,(UAQ) aimed at investigating both students' and teachers' perceptions and attitudes towards the use of (L1) in the EFL classrooms. To achieve this, the researcher used both qualitative and quantitative research methods. Thus, it surveyed one hundred fifty (150) secondary students and fifty (50) teachers of English and observed three (3) EFL classes. The data were collected through two questionnaires and classroom observations. The classroom observations were intended to reflect the quantity of (L1) use in the (L2) classrooms. The data collected through the questionnaires were analyzed with the aid of frequency and percentage, those collected through the open-ended question of the questionnaires and the classroom observations were sorted and summarized.

The findings obtained from classroom observations indicated that the respondents support the well-planned use of Arabic (L1) in certain situations in the EFL classrooms. The questionnaire results revealed that (72\%) of the students and $(54 \%)$ of the teachers felt that Arabic (L1) should be used in their EFL classrooms. The findings also showed that $(71 \%)$ of the students and $(56 \%)$ of the teachers thought that cultural, religious, traditional and political concepts and ideas should be taught by referring to the students' native language (L1). What is more, almost all the respondents objected to using the (L1) excessively and untimely in (EFL ) classes. The quantitative data on the percentage of (L1) in EFL classes showed that most of the respondents preferred only $10 \%$ use of mother tongue (L1) in a 50- minute class. No teachers and students answered higher than $20 \%$ and $40 \%$ respectively. In view of these findings, teachers as well as text writers and curricula planners and designers should take the learners' native language (L1) as a teaching / learning tool.
\end{abstract}

Keywords: L1 (Arabic) and L2 (English), EFL classroom, teachers' and students' attitudes

\section{Introduction}

After graduating from university with a B.A degree in English, I was left with the impression that the learner's first language (henceforth L1) or the mother tongue language (henceforth M.T) should rarely be used in the English classrooms. During my first year of teaching English as a foreign language, I was very anxious to apply this principle .I found, later, that this was not always easy. There were occasions that using L1 seemed impossible, especially with beginners. Although I may have used all the available teaching aids to make my students understand, they did not seem to do so. Therefore, I would often turn to the learners' first language. This practice was rather time consuming and frustrating. It also filled me with feelings of "guilt" as though what I did was entirely forbidden in the English classroom. Gradually, I started realizing that leaving the learners' first language outside the English classroom was almost impossible. Through talks, discussions and debates I had with my colleagues, I found out that most of them were also bewildered by the use of L1 in teaching English. All of these factors encouraged me to investigate this hotly debated issue.

\subsection{Background}

The literature on the history of teaching English Language reflects the uncertainties which surround this issue and various positions have been argued (Nation, 2003). (Howatt, 1984) tells us that using L1 in the English Language classroom played an extremely prominent role during the era of the Grammar Translation Method. On the other hand, a 
number of serious objections had been raised with regard to the Grammar Translation Method. Since then, all English teaching methods (i.e. Direct Method and Audio lingual Method, Community Language Learning, Total Physical Response (TPR) and Communicative Language Teaching Method) almost forbade using L1 in the English classrooms, as they considered teacher's primary job was to immerse students in the target language. (Cole 1998, Freemon, 2000, Prodromou, 2001). Overall, researches split into stands: those who support and those who entirely oppose the use of L1 in the English classrooms.

Stern (1992:279) described the role of the L1 in English Language teaching as "one of the most long-standing controversies in the history of language pedagogy. In the following pages, the researcher will outline some of these arguments.

\subsection{Arguments against Using L1 in the English Language Classroom}

Prodromou (2001b), says that the MT has been treated as a taboo subject (also Deller2003), source of guilt, (also Auerbach 1993; Frankenberg-garcia 2000) as a hit of teachers' weakness to teach properly (also Buckmaster 2002).Moreover, L1 has been considered as a waste of time (Januleviciene and Kavaliauskiene 2002).

Despite these opinions, recent years have witnessed a fairly great shift of views among the English Language teaching professionals concerning the usefulness of learners' first language in the English classroom arguing that classroom use of the learners' first language has certain advantages in some ways (Reis 1996; Cole 1998; Frankenberg-Garcia 2000; Harmer 2001; Deller 2003).

\subsection{Arguments in Favor of Using L1 in English Classrooms}

There are many studies which strongly show that using L1 in the English classrooms can be productive or may even be essential (Bolitho 1983; Urgese 1987; Atkinson 1987; Murakami 1999; Harmer 2001; Rrinvolucri 2001; Prodromou 2001). (Nunan and Lamb 1996; Harmer 2001) give useful pieces of advice on the importance of the occasional use of learners' first language.

Harbord (1992) supports the above researchers for employing L1 and adds that L1 can enhance and keep the flow of communication. (Butzkamm (2003) cited in Judallah \& Fuad (2010) summarizes the principles and advantages of using L1 as follows:-

- L1 use gives a sense of security and helps learners to be stress-free.

- $\mathrm{L} 1$ is the greatest asset people bring to the task of EF learning.

- A foreign language friendly atmosphere is best achieved through selective use of the L1.

- The use of the L1 saves learners from a feeling of frustration they might have within their foreign language learning.

- L1 techniques allow teachers to use richer and more authentic texts, which mean more comprehensible input and faster acquisition.

- All newly-acquired foreign language items have to sink roots in our minds which are eventually deep enough for the items to function independently of the L1.

Another argument favoring the use of L1 comes from Sharma (2006) suggests that L1 might be used for explaining and defining some new vocabulary items and concepts, giving instructions, explaining some complex grammar points, chatting with learners, checking learners comprehension and providing feedback and error correction.

Balosa (2007) suggests that using the students' L1 in class helps them achieve the instructional goals, improves their self-image and motivation, and overcomes some of the limitations of the English-only instruction.

Atkinson (1987:242-243), offers three reasons for allowing limited L1 use in English classrooms (henceforth L2 classroom):

\section{- As a learner-preferred strategy:}

Translation techniques form a part of the preferred learning strategies of most learners in most places. If learners are given the chance, they will choose to translate without the teacher's encouragement.

\section{- As a humanistic approach:}

To allow learners to say what they really want to say sometimes is surely a valuable "humanistic" element in the classroom. Clearly, once it is established what the learners want to say, the teacher can then encourage them to find a way of expressing their meaning in English or, if necessary, help out.

\section{- As an efficient use of time:}


Techniques involving use of the mother tongue can be very efficient as regards the amount of time needed to achieve a specific aim, if only because in general, such techniques need the help of only a blackboard . And assuming that the teacher either shares the L1 of the learners or has sufficient competence in it, many of the techniques involve little preparation.

Acknowledging the importance of the occasional use of L1, Willis (1981: XIV) on her parts indicates that there are times to drop English, for example, to explain the meaning or use of a new word, to explain the aim of the lesson or the activity, to check students' understanding after the presentation, and to discuss the main ideas after a reading passage in pairs.

According to Stern (1992), L1 is considered as a facilitator for learning L2. In other words, comparing the two languages may in fact aid learning processes. Chavez (2002) claims that students prefer using both L1 and L2 because the classroom is not a real context for L2 social culture.

Storch and Wiogglesworth (2003:760) argue that L1 can give learners "cognitive support" that provides them with the ability to explore language and produce work that is of higher standard. They also suggest that teachers should not prohibit the use of some L1 altogether in group or pair work, but should acknowledge that the use of L1 may be a normal psychological process that allows learners to initiate and sustain verbal interaction. For emphasizing this issue (i.e. psychological process), Schweers (1999) cited in Hopkins (1998:18) for instance, writes "If a learner of a second language is encouraged to ignore his/or her native language, he /or she might feel his/or her identity threatened." Echevarria and Grave (1998) point out that when students' native language is welcomed into the classroom, they feel that their language is respected and valued. Nation (1990) cited in Tang (2002:37) believes that "the degradation of the mother tongue has harmful psychological effect on learners." Langer (2001) argues that by permitting the MT in the classroom teachers can give their students a valuable tool to arrive at a meaningful communication. If one is banned from using his/or her MT, one feels he/or she relegated to a position of unimportant. Auerbach (1993:19) says, "Starting with L1 provides a sense of security and validates the learners' lived experiences, allowing them to express themselves. Also (Auerbach 1993: 19) "the use of the L1 reduces psychological barriers to English learning and allows for a more rapid progression."

According to Murakami (1999) using MT establishes identity and therefore should neither be neglected nor subordinated to any languages.

Deller (2003) believes that L1 is an excellent resource for learners who are at lower level of L2 learning if it is used effectively. Deller (2003:3) demonstrates seven possible uses of L1:

- It is useful to notice differences and similarities between the two languages.

- Learners can enjoy materials that might otherwise be too difficult for them.

- Learners can develop and produce their own materials including their own tests.

- Allowing the use of MT can encourage spontaneity and fluency.

- Using MT can equip learners with words and expressions they really want and need in English.

- Using MT can have beneficial effect on group dynamics.

- Using mother tongue ensures that learners are able to give ongoing feedback.

From a socio-cultural point of view, (Kramsch 1993) cited in Beressa (2003) says that through the culture that the MT embodies, teachers can facilitate the progress of their students towards the other cultures, the other tongues. In other words, using L1 would bridge the gap between L1 and the target language cultures.

In accordance with Kramsch, Choffey (2001) has also demonstrated that students' L1 culture and physical environment are of great help in designing L2 classroom activities. He lists three major reasons for using the L1 cultural physical environment to learn the L2:

- To link the activities to the students' experience.

- Students learn how to deal with specific lexical items between the L1 and the L2 cultures.

- To establish firm relationships between L1 and L2.

Prodromou (2002) provides a set of metaphors that illustrate the meaning of the MT in the language classroom. According to him, L1 is:

- " a drug ( though with therapeutic potential, it can damage your health any may become addictive);

- a reservoir ( a resource from which we draw); 
- a wall ( an obstacle to teaching);

- a window ( which opens out into the world outside the classroom ; if we look through it we see the students' previous learning experience, their interest, their knowledge of the world, their culture);

- a crutch( it can help us to get by in a lesson, but it is a recognition of weakness);

- A lubricant (it keeps the wheels of a lesson moving smoothly; it thus saves time)."

\subsection{Reasons for Using L1 by Teachers' and Students}

There is a wide range of ways for both teachers and students to use the L1.Teachers can take advantages of their students' L1 in a number of occasions. Atkinson(1987:244-245) has suggested the following as an area of foreign language teaching where teachers can make use of L1: eliciting language, giving instruction, checking learners' comprehension, classroom management, checking for sense, presentation and reinforcement of language and testing. Agreeing with many of these uses (Cole1998; Buckmaster2000; Cook 2001b) suggest that teachers can use L1 as a way to: explain the meaning of abstract words, introduce the main differences in grammar and pronunciation between L1 and L2, organize class, maintain discipline, gain contact with individual students and test. Piasecka (1988) cited in Auerbach (1993:21) has listed the following possible cases for using MT: negotiation of the syllabus and the lesson, keeping record, classroom management, scene setting, language analysis, presentation of rules governing grammar, phonology, morphology and spelling, instructions, explanation of errors and assessment of comprehension. Urgese (1987:39-40) shows that teachers can use L1 to check writing and reading comprehension exercises, to be utilized as an effective tool in teaching and testing listening comprehension.

(Dajani 2002:65) suggests that L1 can be used by teachers to raise awareness of their students' styles and the strategy they use.

Regarding the use of L1 in the L2 classroom by the students, Harmer (2001) says that the choice of the task will also influence language choice. A more complex and difficult task will discourage the students from using the target language (Robison, 2001 cited in Carless, 2008). In addition, "lack of confidence, fear of making mistakes and peer pressure" will affect language choice (Tsui, 1996 cited in Carless 2008:332). Students tend to use the MT, which refer to what Harmer (2001) identifies as "pedagogical task". These include

- Co-operation among learners (Atkinson (1987). When students work in groups or pairs it is expected, especially in lower levels, to use the L1 (Atkinson1987) because they use it to improve their understanding of the language (Harmer 1994) cited in Carless, 2008).

- Asking questions for help from teachers or peers(Cameron 2001)

- Responding to teachers' questions (Cameron 2001).Answer in the L1 is definitely better than remaining silent.

Cook (2001:417) suggests three cases that might lead learners to use their L1:

- As a part of the main learning activities.

- Within classroom activities (group / pair work)

- As a way to the meaning of L2 words both inside and outside the classroom(e.g., the use of bilingual dictionaries)

According to Cook (2001b) cited in (Beressa 2003), L1 provides a scaffolding help: through L1 students may explain the tasks to each other, negotiate the role they are going to take, check their understanding or production of the language against their peers. According to him, L1 is especially helpful when the activities involve problem solving in which case students could put their heads together and discuss the solution to the problem(s).

Harbord (1992: 354) agrees with Cook's (2001b) point of view concerning L1 roles. Harbord explains that L1 has a variety of roles:

- Explanation by students to peers who have not understood.

- Giving individual help to weaker students during pair or group work

- Giving help to student-student comparison or discussion.

With regard to instructions, Atkinson (1987) states that low level students often find it difficult to understand instructions given in the target language. So, it is very useful to give instructions in the learners' L1 so that they can understand what the teacher is asking them to do. Gill (2005) supports the idea of using L1 for classroom management. Swain and Lapkin (2000) suggest that L1 use may enable learners to perform tasks more efficiently and successfully. In many issues, it may not desirable to teachers only in the target language, since this creates an impression of ethnocentricity if the L1 is banned (Atkinson 1993 cited in Sharma (2006). 


\subsection{Conclusion}

The learners' L1 in the second language classroom has been a point of controversy. In fact, there is no rule that you should never use L1 in learning English, nor is there any excuse for using L1 most of the time. Some researchers see its use as a negative and harmful to the teaching- learning process while others see it as a valuable and precious tool. Those who support the use of L1, though, do not suggest that it should be used all the time, but it can be effective in certain situations (Auerbach, 1993:9, Hawks, 2001:51). Atkinson (1987:247) says "Although the mother tongue is not a suitable basis for a methodology, it has, at all levels, a variety of roles to play which are at present, consistently undervalued." To conclude, many researchers have found that Butzkamm's (2003:38) words were most appropriate:

"We should finally free ourselves of a fundamental misconception and re-establish the more than 200-year-old productive alliance between the mother tongue and the foreign language."

\subsection{Role of L1 in English Language Teaching Methodologies}

(Larsen-Freeman 2000) cited in Nazary (2008, P 141-142) supports the role of the MT in the classroom procedures and summarizes the role of $\mathrm{L} 1$ in various EFL methods:

\section{Grammar- Translation Method}

The meaning of the target language is made clear by translating it into the students' native language. The language that is used in the class is mostly the students' native language. (P.18)

\section{Direct Method and Audio lingual Method}

The students' native language should not be used in the classroom because it is thought that it will interfere with the students' attempts to master the target language. (PP.30 and 47)

\section{Silent Way}

The students' native language can, however, be used to give instructions when necessary, and to help a student improve his/or her pronunciation. The native language is also used at beginning levels of proficiency during feedback sessions.

\section{Suggestopedia}

Native language translation is used to make the meaning of the dialogue clear. The teacher also uses the native language in the classroom when necessary. As the course proceeds, the teacher uses the native language less and less. (P.83)

\section{Community Language Learning}

Students' security is initially enhanced by using their native language. The purpose of L1 is to provide a bridge from the familiar to unfamiliar. Also, directions in the class and sessions which students express their feelings are conducted in their L1 (PP.101-102)

\section{Total Physical Response (TPR)}

This method is usually introduced initially in the students' native language. After the lesson introduction, rarely would the native language be used. Meaning is made clear through body language. (P.115)

\section{Communicative Language Teaching}

Judicious use of the students' native language is permitted in communicative language teaching (P.130)

In Conclusion, the learners' native language has had a variety of functions nearly in all teaching methods except in the Direct Method and Audio Lingual Method. Those methods had their theoretical underspinnings in structuralism and assumed language learning to a process of habit formation, without considering learners' affect, background knowledge and their linguistic abilities in the L1. Besides, no attention was given to humanistic views of teaching.

\subsection{Significance of the Study}

It is hoped that the findings of this study will provide some insights to the following groups:

* Curricula-planners, syllabus designers, supervisors and adaptation committee may design appropriate training courses to overcome the problems that hinder the development of teaching- learning processes and to take into consideration the learners' first language while constructing appropriate syllabuses and designing remedial courses.

* English Language teachers may make use of the findings of this study and become aware of the role of L1 plays in teaching- learning situations. 
* Methodologists may conduct further researches in the area that may open the way to the development of new English language teaching methods that incorporate using L1 (Arabic) in the English classrooms.

* Teacher educators could aid them to re-examine their foreign language teaching methodology at the teacher training centers.

Finally, the findings of this study could be very necessary in raising our awareness of where we are at present in our use of L1 and in preparing a solid ground for a more logical use of Arabic (L1) in the English teaching classrooms.

\subsection{Limitations of the Study}

1) Initially, this study was intended to be conducted on two educational zones (i.e. Umm Al-Quwain( henceforth UAQ) and Ajman) Educational Zones. But, due to the time constraints and being a teacher at UAQ for more than nineteen years, I was forced to drop one of the two zones Which was Ajman Educational Zone.

2) The study was confined to male and female students in the secondary cycle at Al-Ghad Schools at U.A.Q Educational Zone in the UAE in the year 2011/2012. Therefore, the generalization of the results of this study was confined to this population and similar ones.

3) The results of this study depended on the validity and reliability of the instrument constructed by the researcher himself.

\subsection{Definition of Terms}

The following terms will have the associated meanings whenever used in the text.

1) Attitude: - a disposition or tendency to respond positively or negatively towards a certain idea, object, person and situation.

2) Perception:- the way you think about something and your idea of what it is like.

3) L2:- refers to a second or a foreign or a target language learned. The terms "second" and "foreign" have been used interchangeably to mean the same thing. Moreover, in most cases these terms refer to the English Language.

4) L1:- refers to a person's mother tongue or the language acquired first. Often this term is used synonymously with native language.

5) EFL: - refers to the study of English as a foreign language, as is the case in the UAE. There are usually no real opportunities to use English outside the classroom.

\subsection{Objectives of the Study}

The main aim of this study is to find out whether the use of L1 in the L2 classrooms would assist or encounter the teaching - learning process from teachers' and students' attitudes. More specifically, the study tries to seek answers to the following questions:

1) What are the teachers' and students' attitudes toward using L1 (Arabic) in the English classrooms?

2) For what purposes do they use the L1?

3) How frequently do teachers and students use L1 in the English classrooms?

4) To what extent do teachers of English Language and students believe in the role of L1?

5) How often do students want their teachers to use L1 in the English classrooms?

6) How often do students want to use L1 in the English classrooms themselves?

7) What are the factors which affect teachers' decisions about using Arabic (L1) in the L2 classroom?

8) What is the L1 proportion during the English Lessons from teachers' and students' perspectives

\section{Review of Related Literature}

This chapter presents a review of the previous studies that are relevant to the use of learners' native language (L1) in the EFL classrooms. This review is divided into two sections. The first section deals with arguments that confute the use of (L1) in the EFL classroom. The second section discusses the arguments favoring the use of (L1) in the EFL classrooms. 


\subsection{Arguments that Confute the Use of (L1) in the EFL Classes}

A number of studies object to using the learners' native language (L1) in the EFL classrooms.

Cook (2001 b) presents three main arguments against using (L1) in the EFL classrooms:

\section{A. The (L1) acquisition arguments.}

The philosophy behind this claim is that adults learn L2 in a similar way children learn their mother tongue (L1). This justification for this claim is that (L1) acquisition does not depend on another language or children in the (L1) cannot fall back on another language. In my opinion, it is mistaken to generalize what is true for children is also true for adults as far as language learning is concerned.

\section{B. The language compartmentalization.}

This suggests that successful (L2) acquisition relies on keeping the (L2) separate from (L1) and seeing the (L1) and the (L2) as separate entities. Therefore, (L1) was not needed during the process of learning a second language since it had a separate system. Supporters of the monolingual approach believed that " the native language and the target language have separate linguistic system; they should be kept apart so that the students' native language interferes as little possible with the students' attempt to acquire the target language." ( Larsen-Freeman,2000, p.42).To Cook(2001b) one main reason for thinking in this way is the fear of (L1) interference.(p.406).More research findings Harbord(1992) supported keeping the two languages apart and he conceded that overusing (L1) makes students believe that a word by word translation (literal translation) is a useful technique. But in fact this was not found between languages. For example, (the boy is handsome) and (the girl is beautiful), so students make literal translation from Arabic as (the boy handsome and (the girl beautiful) because Arabic does not have verb to be, i.e copula be.

\section{The maximum provision of the (L2) argument}

This is the most common argument against the use of (L1) in the (L2) classroom. (Tang, 2002). The idea is that the (L2) learners often have little or no exposure to the target language outside classroom. It follows; therefore, that teachers should not spend too much time using (L1). According to Cook and Turnbull, teachers can maximize the use of the target language without ignoring the learners' first language (L1). "A principle that promotes maximum teachers' use of the target language acknowledges that (L1) and (L2) can exist simultaneously." (Turnbull, 2001, p.535).

Atkinson (1987) argued that the use of (L1) created the following problems:

A. The teacher and/or the students begin to feel that they have not really understood any item of language until it has been translated.

B. The teacher and/or the students fail to observe distinctions between equivalence of form, meaning, and pragmatic feature, and therefore, students tended to oversimplify to the point of using inaccurate translation.

C. Students speak to the teacher in the (L1) even though they are able to express what they mean.

Ellis $(1985 ; 1994 ; 2005)$ as cited in Qadri (2006, p.15) adapted a strong position against (L1) use in the EFL classroom. He explained that "To maximize the use of (L2) in the classroom ideally means that the (L2) needs to become the medium as well as the object of instruction." (Ellis, 2005, p.10). He described a study conducted at Auk land Secondary Schools which revealed that teachers of French, German, Japanese, and Korean used (L2) between 88\% to 22\% of the total (L2) input. He criticized this variation in the extent of (L2) use in the EFL classrooms, and recommended that all classroom interaction between teachers and students should be conducted in (L2). He emphasized that "Everything the teacher does or says in the (L2) classroom provides an opportunity for learning the new language, and the use of (L1) deprives students of valuable opportunities to use, communicate and process (L2).”(p.10).

Ellis called for more use of (L2) for classroom management because these were common functions of classroom communication. He also advised teachers to create opportunities for students to receive (L2) input outside the classroom such as encouraging graded extensive reading programs appropriate for the students' level.

Karma and Hajjaj (1989) conducted a study on Arab learners in the Gulf region and concluded that (L1) should not be used in (L2) classroom since the main aim of second language is to approximate near-native competence (p. 228). They also added that the use of (L1) hinders (L2) fluency, reduces motivation and creates in learners the expectation that the (L1) will be used. Also, the use of (L1) reduces both the exposure learners get to the (L2) and their opportunities for using it.

Phillipson (1992) argues that "The more English is taught, the better the results." (p.185). In accordance with the previous view, Auerbach (1993) also indicates that "The more students are exposed to English, the more quickly they will learn; as they hear and use English , they will internalize it and begin to think in English." (p.14). Comparably, 
Polio and Duff (1994) show that using (L1) "prevents students from receiving input they might be exposed to in social situations outside the classroom."(p.322). Macdonald (1993) as cited in Sharma (2006) argues that switching to (L1) to explain what the teacher has said to the learners is unnecessary and undermines the learning process.

The conclusion to be drawn from this review of literature is that it is better and more beneficial to teach and learn English through the medium of English.

In the following section, arguments that support the use of (L1) in the EFL classroom are presented:

\subsection{Arguments that Support the Use of (L1) in the (L2) Classroom}

There are several studies that have been carried out during the past years with the aim of investigating students' and teachers' attitudes towards the use of (L1) in (L2) teaching in different contexts, and identifying specific situations in which (L1) should be used in the (L2) classrooms. (Duff and Polio, 1990; Py, 1996; Schweers, 1999; Macaro, 2005; Al-Makhzoomi and Ahmed, 2005; Storch and Aldosari, 2010).

Mukattash (1984) points out that contrasting the (L1) and (L2) can facilitate the learning of the new language. Similarly, Hopkins (1989) adds that (L1) use might increase learners' confidence. Atkinson (1987) emphasizes the strong recommendation of using (L1) in (L2) classroom when dealing with presentation of rules governing grammar, phonology, morphology and spelling. He also recommends referring to (L1) when dealing with cross-cultural issues.

Tushyeh (1990) cited in Hamdallah (1999) conducted a study on two-hundred and thirty one English teachers from governmental, private and UNRWA schools in the West Bank. His tool was a questionnaire that dealt with the English Language teaching situation there. One item in the questionnaire dealt particularly with the use of Arabic in the EFL classes in schools and universities in the West Bank. He found that the participants agreed with the conviction of the communicative approach which allows limited use of (L1).It is also agreed in literature that native language(L1) could be used by EFL teachers to give instructions to early levels and low level achievers. Harbord (1992) emphasized that giving class instructions by using (L1) is an important point to achieve and facilitate communication between students and teachers. In their studies Cook (2001); Shimizu (2006); Nazary (2008) and Al-Nofaie (2010) found that a large number of teachers' favorite choice for giving complex instructions was by using the learners' first language.

According to Auerbach (1993), "When the native language is used, practitioners, researchers and learners consistently report positive results."(p.18). She also gives a socio-political rationale for the use of (L1) in the ESL classroom. She emphasizes the role of the ideological origins and thus she recommends starting the (L2) classes with some of (L1) which has the power to enrich the learners' sense of security and the validation of lived experiences.

A study carried out by Doyle (1997) shows that sometimes, up to 90\% of ESL class time be dedicated to the use of (L1). Another study of (L1) use in the EFL classroom was carried out on five native English speaking adults learners of Spanish as a second language(L2) by Anton and Di Camilla(1998) found that using (L1) in pair/group work provides learners with scaffolding help. In the analysis of the learners' collaborative speech, they discovered that learners used (L1) to carry out the following uses:

A. Developing strategies for making the task(s) manageable.

B. Maintaining and supporting their focus on the objective of the task.

C. Attracting each other's interest in the task throughout its performance.

D. Discussing what needs to be done to solve specific problems.

E. Explicating and building on each other's partial solutions to the specific problems throughout the task.(p.321)

Schweers (1999) carried out a study on EFL students and their teachers in a Spanish context to investigate their attitudes towards using (L1) in the (L2) classroom. He found that the majority of students agreed that Spanish should be used in the EFL classroom. He also noted that $80 \%$ of students found the use of (L1) in the classroom is useful. They believed that using (L1) in the EFL classrooms could be useful and lead to better understanding of text and this made them:

A. feel less lost and less tense.

B. feel more comfortable and confident.

A second language can be learned appropriately through raising awareness to the similarities and differences between (L1) and (L2). Besides, using (L1) in (L2) classes has made learning (L2) appear to be less of threat to its learners. The use of (L1) in (L2) classes encourages students to learn more about (L2). Additionally, the learning of (L1) may result in increasing receptivity to learning of (L2).William (1999) as cited in Makhzoomi and Ahmed (2005).

Using (L1) to motivate students has received some attention in literature. Hamdallah (1999) emphasized that in order to 
keep the learner's motivation in an "ideal circle," appropriate use of (L1) in the EFL classes could be used. He also added that using the students' native language motivates and encourages them to express their ideas since it has a direct influence on the psychological pressure."(p.290)

Critchely (2002) concluded that with lower level learners," teachers should use (L1) when appropriate to build positive and mutually supportive relationships that promote students' motivation."(p.3).Nation (2003) indicates that it is easier and more communicative to use (L1) in the EFL classes to facilitate communication between students and teachers. Butzkamm (2003) declares that students become more motivated to communicate in (L2) by using (L1) inside the classroom since using (L1) use makes them feel more comfortable.

Tang (2002) carried out a study in the Chinese context. The data were collected through interviews and classroom observations. He found that $70 \%$ of students and $72 \%$ of teachers think that Chinese should be used in the EFL classes, but more than half $65 \%$ of students think that the amount of Chinese used should be ranged only 5 to $10 \%$ of classroom time. Students prefer to use Chinese in the EFL classroom since it enhances their comprehension of new concepts and new vocabulary items. While teachers think that the use of Chinese in the EFL classroom is more effective and aid comprehension. Also, he reported that the use of (L1) in the EFL classes does not hinder learning (L2), but it helps teaching and learning.

Al-Makhzoomi \& Ahmed (2005) conducted a study on six hundred male students and thirty teachers of English at Rawdit Al-Ma'aarif School in Amman /Jordan. Their grades ranged between the fifth grades $\left(5^{\text {th }}\right)$ and the twelfth grades $\left(12^{\text {th }}\right)$. They found that $100 \%$ of the students and $90 \%$ of the teachers felt that Arabic should be used in the EFL classes. They also found that the respondents emphasized the fact that cultural and religious concepts should be taught by referring to Arabic in the EFL classes. Following this, they noticed that $85 \%$ of students and $75 \%$ of teachers agreed that Arabic should necessarily be used to introduce grammatical rules.

Sharma (2006) carried out a study on Nepali teachers and students to investigate their attitudes towards the use of (L1) in the EFL classes. The results indicated that all the respondents preferred the occasional use of (L1) in the English classes. They also said that judicious use of (L1) is justified since it helps students learn English better.

Al-Qadumi (2007) conducted a study on eighty teachers to investigate their attitudes towards using Arabic in the EFL classes in Qalqilya and the villages around. He found that the English teachers in Qalqilya district have positive attitudes towards using Arabic in the EFL classes in certain situations when they feel that using Arabic is necessary.

In Gulf region, there has also been some attention paid to the use of (L1) Arabic in the English classes. In Oman for example, Al-Hinai (2006) carried out a study on elementary classroom teachers and their students in Muscat Region to investigate the participants' attitudes and beliefs towards using Arabic (L1) in elementary classes. Data were collected via lesson recording, classroom observations and interviews (Teachers' and students' interviews). He concluded that Arabic was widely used in EFL classes since the students' level of proficiency was low in English .It was frequently used for translation, classroom management and control, but it was never used to explain abstract words.

Al-Alawi (2008) conducted a study on five teachers of English in Batinah North Region in Oman to investigate the teachers' beliefs with specific reference to their use of the (L1) in the English classes. Data were collected through classroom observations and interviews. He found that some teachers resort to Arabic extensively to give instructions and to tell jokes. Surprisingly perhaps, the use of Arabic for classroom management was infrequent. Al-Hadrami (2008) did a study on four Omani English teachers to investigate their views and beliefs about the usefulness of Arabic in English classroom. He found that all the participants agreed that Arabic could be useful in EFL classrooms, particularly for explaining vocabulary and concepts but three out of the four were also opposed to use it excessively. Al-Buraiki (2008) carried out a study to investigate the Omani teachers' attitudes in basic education school. He reported that the teachers believed that (L1) had a positive role to play in teaching young learners. Finally, Al-Shidhani (2009) conducted a study on one hundred and fifty teachers in the Sharqiya North Region of Omani to investigate teachers' beliefs about using Arabic in the English classroom. Data were collected through a questionnaire. The questionnaire had five sections .One was about the teachers' opinions about using Arabic in the English classroom. He reported that the teachers were not compatible with their learners; as while teachers believed that the use of Arabic in communicative classrooms was not compatible with the communicative approach, their learners expect them to make use of it.

Al-Nofaie (2010) carried out a study on students and teachers in Saudi Arabia to investigate their attitudes towards using Arabic (L1) in the EFL classes. He found that the students' and teachers' attitudes were positive towards using (L1) in the EFL classroom, and the students preferred (L1) to be used in certain situations. Teachers emphasized the importance of (L1) in their classes. However, they claimed that the untimely and excessive use of (L1) should be avoided since it hinders learning English.

Jadallah and Fuad (2010) interviewed five English instructors to investigate their attitudes towards using Arabic in the 
EFL classes. They found that all the instructors agreed that using Arabic in the EFL teaching is acceptable since they believed that there were some reasons in which Arabic can be helpful. For example, clarifying abstract words, making students feel more relaxed, saving the class time and checking understanding instructions.

Kim Anh (2010) carried out a study on Vietnamese university teachers to investigate their attitudes towards using Vietnamese (L1) in EFL classrooms. Data were collected through a questionnaire and semi-structured interview. He found that judicious use of (L1) was necessary in some situations in EFL classrooms. Also, all the respondents supported the use of (L1) in EFL classes. They stated that (L1) was a part of their teaching method and could play a positive role in their classrooms.

In conclusion, my experience as a learner and teacher of English Language has shown me that moderate use of the (L1) can help and facilitate learning and teaching of (L2), a view shared by many of my colleagues.

To sum up, this section showed that there were two main stands towards dealing with this issue .One that supported the use of (L1) in EFL classrooms and those who entirely opposed this approach. Moreover, this section provided reasons and examples of the overuse of (L1) in (EFL) classrooms and presented suggestions for supporting and encouraging (L2) use in the classes.

\section{Methodology and Procedures}

This section presents the methodology that the researcher followed in this study. It includes the design of the study, the population and the sample, the instrument, the validity and the reliability of the instrument, the appropriate statistical analysis used to analyze the study results and the procedures of the study.

\subsection{Design of the Study}

In this study both the quantitative and descriptive methods were required, including classroom observations and questionnaire to collect the required data of the study. In fact, the general advantages of using a questionnaire is that it can be distributed and collected easily, and assure the researcher that the information can be easily interpreted and translated.

\subsection{Population of the Study}

The population of this study is all the secondary science and arts students (male and female) studying at Umm AlQuwain Educational Zone Schools, enrolled in the academic year 2011/2012. There are six secondary schools for both males and females.Three for males and three for females. The students have been learning English for about (10-12) years. Classes in which the students were tested provided a heterogeneous mix of high average and low achieving students. The EFL teachers in these schools are qualified, veteran teachers who are experienced in EFL teaching methods. Moreover, the researcher had easy access to these schools.

\subsection{Sample of the Study}

The participants of the study were (150) science and arts, male and female students. (25) students were selected from each grade and the proportion of boys and girls was 50/50.Their age ranged from (16) to (18) .Fifty (50) teachers of English at Umm Al-Quwain Educational Zone Schools with their teaching experience ranging from 5 years to more than 20 years. According to Nunan's categorization, (1992 b), all these teachers belong to the category of experienced teachers. Their highest TEFL qualification ranges from B.A. to M.A. Like the students, all of them speak the Arabic Language.

\subsection{Instrumentation}

For the purpose of soliciting information needed to achieve the objectives of the study, the following instruments were used:-

\subsection{The Questionnaire}

After reviewing the relevant existing literature, the researcher developed a questionnaire which is adapted from Tang (2002), Makhzoomi and Ahmed (2005) and Sharma (2006) to find out the attitudes of teachers' and secondary students towards using Arabic in the English classrooms.

\subsection{Validity of the Questionnaire}

For the purpose of validating the questionnaire, a jury of (5), (3) TDSs teachers Development Specialists and (2) ILCs Instructional Leadership coordinators were kindly asked to judge whether the items were enough, appropriate and comprehensive. This resulted in the addition of some items and the omission of others that were vague and misleading in response to the jury's suggestions. 


\subsection{Reliability of the Questionnaire}

The reliability of the questionnaire was measured by administering it on a pilot sample consisting of (20) female and male students and (10) school teachers at UAQ Educational Zone who were chosen from outside the sample of the study. Cronbach Alfa formula was calculated for the three domains of the teachers' and students' questionnaires. All the percentages were acceptable for the purpose of this study. Table 1 shows the reliability of the three domains of the teachers' and students' questionnaires

Table 1. Reliability of the three domains of the teachers' and students' questionnaires

\begin{tabular}{l|c}
\hline \multicolumn{1}{c|}{ Domain } & Cronbach alpha \\
\hline Participants' opinion towards using Arabic in the English classroom & Students:- 0.80 \\
& Teachers:- 0.77 \\
\hline Occasions Arabic used & Students:- 0.91 \\
& Teachers:- 0.82 \\
\hline Effectiveness of Arabic in the English classroom & Students:- 0.77 \\
\hline
\end{tabular}

\subsection{Statistical Analysis}

From the observed data, the total number of occasions on which the Arabic Language was used during the six lessons were counted using the word as a unit of measurement.

The responses obtained from the students' and teachers' questionnaires were tallied and the frequencies were converted into percentages. Percentage value was used because it is easier to compare taking into account the fact that a different number of students and teachers participated in the study. The open-ended questions of the questionnaires were sorted out and summarized.

The data obtained through the two tools were interpreted and discussed to arrive at sound conclusions regarding the use of the Arabic Language in the English classroom. An attempt was also used to link the discussions and interpretations with the works reviewed in the review of related literature and previous studies section.

\subsection{Questionnaire}

A questionnaire was distributed to (150) students and another questionnaire to (50) teachers to find out their attitudes towards using Arabic in the English classroom. The questionnaire items focused on the participants' opinions towards using Arabic, the different occasions on which they think Arabic can be used, and the perceived effectiveness of Arabic in the English classroom. Both types of questionnaire had items, which were a mixture of close-ended and open ended, and were set in English. Some of the items were in fact adapted from Tang (2002) in such a way that they suit the purpose of the study. The administration of the students' questionnaire was conducted in my own presence and some EFL teachers in these schools. Students were given enough time to read each item at their own convenience and fill in their genuine response appropriately. My presence had helped them to clear up some of the misunderstandings that they faced while completing the questionnaire.

All the questionnaires administered to students and teachers were filled out and returned. Furthermore, (50) have been excluded of (200) students', because their papers were unintelligible or irrelevant.

\subsection{Classroom Observations}

Three randomly - selected teachers reading classes (1 class from grade 10, 1 from grade 11 and 1 from grade 12), 50 minutes in length- conducted by three teachers were observed to discover how frequently and on which occasions Arabic was used in the English classroom. To obtain authentic data, the teachers and students were not informed of the observation purpose beforehand. The classroom observation was felt to be suitable for the study for the following reasons. Firstly, it was aimed to generate in depth information from the students and teachers on the matters related to the use and non-use of the students' first language in the English classroom. Secondly, it was used as a follow-up to the data obtained through the questionnaires.

\subsection{Procedures of the Study}

1. Getting the permit from Umm Al-Quwain Educational Zone (UAQ) to collect data from the designated secondary schools.

2. Choosing the sample of the study randomly.

3. Reviewing the related literature to establish the theoretical part of the study and to report related practical studies. 
4. Preparing the questionnaire and establishing its validity.

5. Attending the subjects' classes during February 2012 and distributing the questionnaire personally to the students. By attending personally, the researcher could answer students' questions about the questionnaire and explain any item students did not understand. Students took about (60) minutes to complete the questionnaire.

6- Visiting the school teachers during February 2012 and distributing the questionnaire personally to them.

6. Getting the results and analyzing them in light of the questions of the study.

7- Drawing conclusions according to the results of the study.

\section{Results and Discussions}

\subsection{Classroom Observations Results}

Table 2. The frequency and occasions that teachers and students used Arabic in the three 50-minute reading classes

\begin{tabular}{|c|c|c|c|c|c|c|c|c|c|c|c|}
\hline \multicolumn{12}{|c|}{ Teaching Stages } \\
\hline & \multicolumn{4}{|c|}{ Pre-teaching } & \multicolumn{3}{|c|}{ While-Teaching } & \multicolumn{4}{|c|}{ Post- Teaching } \\
\hline Teacher & 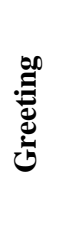 & 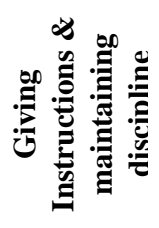 & 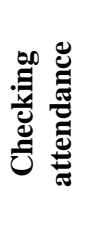 & 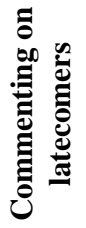 & 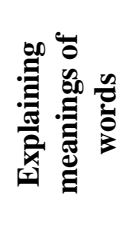 & 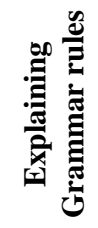 & 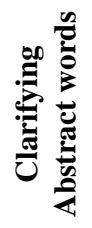 & 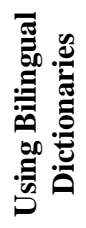 & 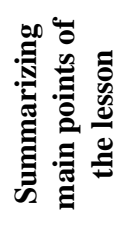 & 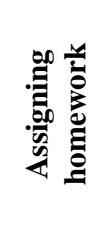 & हేّ \\
\hline Teacher 1 & 1 & 5 & 1 & 0 & 1 & 1 & 3 & 1 & 0 & 1 & 14 \\
\hline Teacher 2 & 0 & 2 & 0 & 0 & 3 & 1 & 1 & 0 & 0 & 1 & 8 \\
\hline Teacher 3 & 1 & 1 & 1 & 1 & 4 & 2 & 0 & 0 & 0 & 1 & 11 \\
\hline Total & 2 & 8 & 2 & 1 & 8 & 4 & 4 & 1 & 0 & 3 & 33 \\
\hline
\end{tabular}

From table (2), it is clearly noticed that Arabic was used by the three teachers in the three-level English reading classes in the three different teaching stages: Arabic was used during the Pre-teaching stage, to greet the students, to give instructions and maintaining discipline, to comment on latecomers, to check attendance and in while- teaching stage to explain meanings of words, to explain grammar rules, to clarify abstract words and to use bilingual dictionaries. While in the post-teaching stage, it was used to assign homework and summarize the main points of the lesson. All the three teachers were from government schools. The greatest use of Arabic among the three stages, (9) times, was to give instructions and maintain discipline, followed by explaining meanings of words, clarifying abstract words, and explaining grammar rules as well as checking attendance.

Teacher (1).Teacher (1) was a male with a teaching experience of (7) years. He used Arabic (5) times to give instructions and maintain discipline. For instance, first, he said "Open your workbook page (54)," but there were still some students who opened the student's book on page (82). Then he used Arabic. Secondly, "Go and throw the chewing gum in the dustbin," but there was still one student using it. Then, angrily he used the student's L1 (Arabic). Thirdly, he used L1 to warn a student playing with the mobile phone. Fourthly, he used L1 to warn a student talking with his friend. Fifthly, he ordered a student to go to the secretary to bring some papers.

Teacher (2) .Teacher (2) was a male with 19 years of teaching English for secondary level. He was the teacher to use L1 least (8) times in 50- minute classroom. He used Arabic (3) times to explain the meaning of difficult words: (devastating, excruciating, and prevail) after his English explanations, (2) times to maintain discipline at the beginning of his class, Most surprisingly, he used the students' native language (L1) equal number (1) time to explain one grammar rule (regular and irregular forms of the past tense), to clarify the meaning of the abstract word (wisdom), and to assign homework.

Teacher (3). Teacher (3) was a female teacher with her teaching experience of (9) years. The largest number of times (4) she used Arabic to explain the meaning of the difficult words: daunting, leverage, trim and puppy. Whenever she felt that her students did not understand her, she returned to the students' native language (i.e. Arabic). She also used the students' first language (L1) (2) times to explain grammar rules. (The difference between definite and indefinite articles). Also, she used L1 equal number (1) time for greeting the students, for maintaining discipline, for commenting on a latecomer, for checking attendance and for assigning homework. To my astonishment, none of them used L1 for summarizing main points of the lesson.

The three class observations show that Arabic is used on occasions when English explanations were fruitless, for this reason Arabic (i.e. the student's L1) benefits both teachers and students, although students wanted more L1 than 
teachers. This supports Tang and Schweers' research, which state that L1 can play a "supportive and facilitating role" (Tang 2002, p.41) in the English classroom although English should be "the primary vehicle of communication." (Schweer, 1999, online).

\subsection{Questionnaires Results}

As mentioned earlier, questionnaires were distributed to 150 students and 60 teachers of English, 55 were returned .Furthermore, (5) were excluded of (55) teachers of English, because their responses were unintelligible or irrelevant. Following is the questionnaire with a table and figure showing the respondents' responses to each of its question:

Question (1).In your opinion, do you think that Arabic should be used in the English classrooms?

Table 3. Respondents' perspectives of using Arabic in English classrooms

\begin{tabular}{c|c|c}
\hline Response & Students & Teachers \\
\hline Yes & $72 \%$ & $54 \%$ \\
\hline No & $28 \%$ & $46 \%$ \\
\hline
\end{tabular}

Table (3) shows that a high percentage of the students (72\%) and more than half of the teachers (54\%) who participated in the study realize that Arabic should be used in the English classroom.

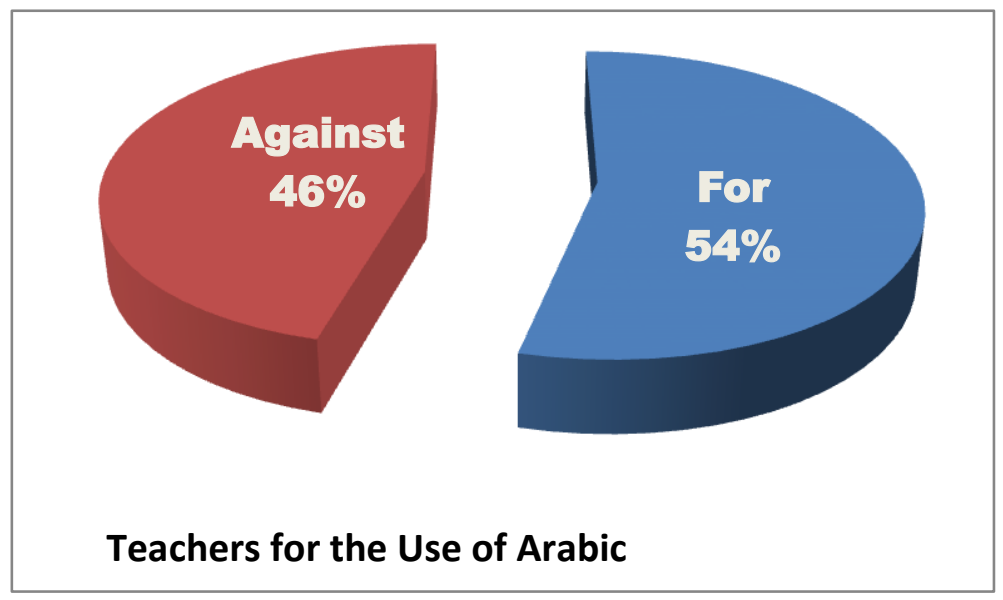

Figure 1. Teachers' attitudes towards the use of L1 (Arabic) in EFL classroom

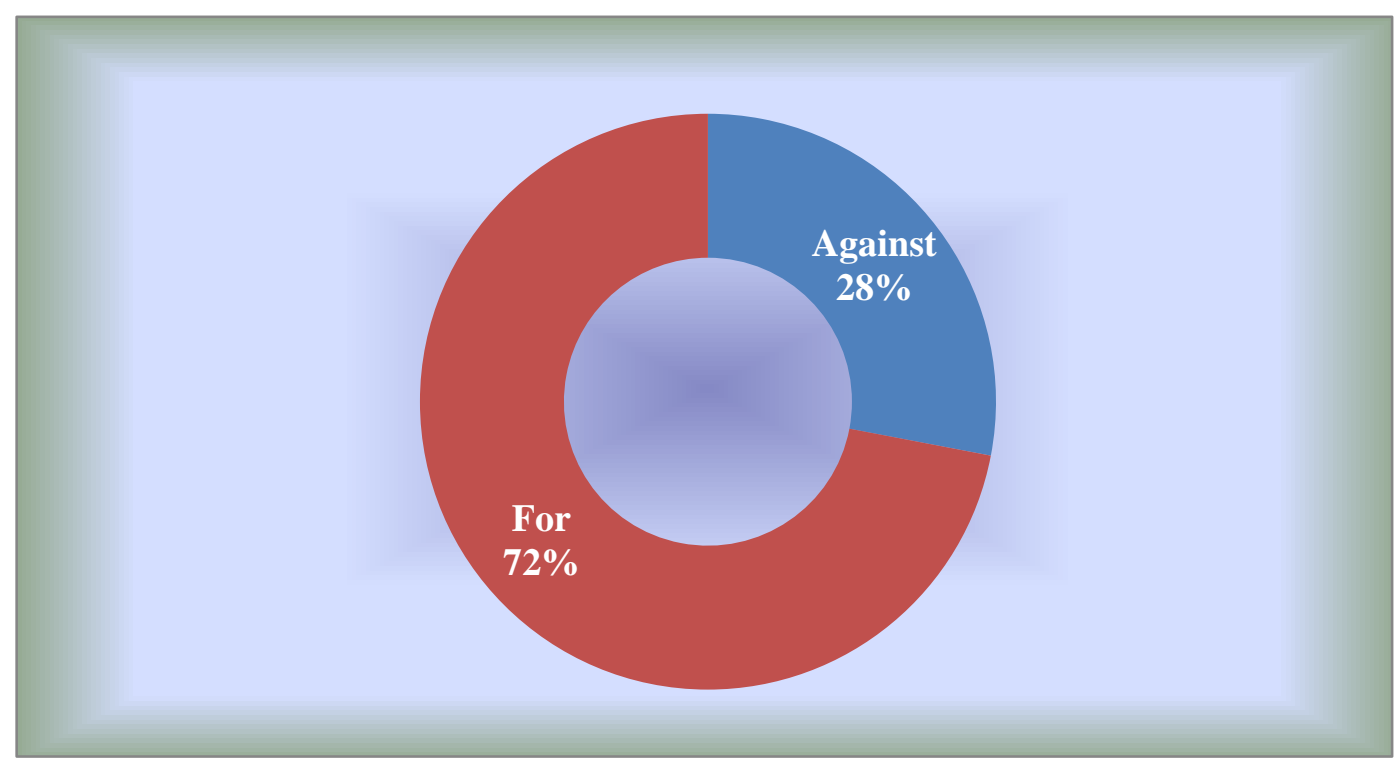

Figure 2. Students' attitudes towards the use of Arabic in EFL classroom 
Question (2) For what purpose do you think it is useful to use Arabic in the English classrooms?

Table 4. Respondents' Perspectives of the Purposes of Using Arabic in EFL Classrooms.

\begin{tabular}{|c|c|c|c|}
\hline No & Purposes & Students\% & Teachers\% \\
\hline $1-$ & To explain difficult religious, traditional, cultural and political concepts and ideas. & 71 & 56 \\
\hline $2-$ & To help students feel more comfortable, confident and less stressed. & 51 & 10 \\
\hline $3-$ & To allow me to express things which are difficult to say in English. & 31 & 16 \\
\hline 4- & To present and explain complex grammatical rules. & 29 & 34 \\
\hline $5-$ & To give weak learners a chance to improve. & 24 & 30 \\
\hline 6- & To define some new vocabulary items. & 23 & 30 \\
\hline $7-$ & To give instructions for teaching tasks and exams. & 22 & 10 \\
\hline $8-$ & To compare between structures in Arabic and English. & 21 & 28 \\
\hline 9- & To allow students to say what matters to them. & 20 & 2 \\
\hline $10-$ & To prevent myself from committing errors in English & 15 & 2 \\
\hline $11-$ & To arrange for pair/ group work. & 14 & 0 \\
\hline $12-$ & To facilitate teacher-student relationship. & 13 & 8 \\
\hline $13-$ & To save class-time and confusion. & 13 & 10 \\
\hline $14-$ & To create a more relaxing learning environment. & 13 & 4 \\
\hline $15-$ & To comment on latecomers. & 9 & 4 \\
\hline $16-$ & To maintain discipline and class control. & 7 & 12 \\
\hline $17-$ & To assign homework. & 5 & 2 \\
\hline $18-$ & To take attendance. & 5 & 2 \\
\hline 19- & To sum up material already covered. & 3 & 2 \\
\hline $20-$ & To discuss students' personal problems outside the classroom. & 10 & 22 \\
\hline
\end{tabular}

Table(4). Results of the questionnaires on purposes of using Arabic in an English classroom.

Note: Where participants could circle more than one answer to a question (items $2 \& 3$ ), totals add up to more than 100 percent.

When asked the students about their perspectives of the purposes of using Arabic in the EFL classroom, many students (71\%) replied that Arabic should be used to explain difficult religious, traditional, cultural and political concepts and ideas, followed by $(51 \%$ )who think that Arabic should be used to help students feel more comfortable, confident and less stressed. (31\%) students think that Arabic should be used to allow them to express things which are difficult to say in English, (29\%) think that it should be used to present and explain complex grammatical rules, (24\%) think that Arabic should be used to give weak learners a chance to improve, $(23 \%)$ think that it should be used to define some new vocabulary items. (22\%) think that Arabic should be used to give instructions for teaching tasks and exams, (21\%) think that student's mother tongue language should be used to compare between structures in Arabic and English. (20\% )think that Arabic should be used to allow students to say what matters to them. (15\%) think that it should be used to prevent oneself from committing errors in English, (14\%) of the students think that L1 should be used to arrange for pair/group work, (13\%) think that Arabic should be used to facilitate teacher-student relationship, to save class-time and confusion and to create a more relaxing learning environment. While (10\%) of the students believe that Arabic should be used to discuss students' personal problems. (9\%) of them think that Arabic should be used in the English classroom to comment on latecomers.(7\%)of the students feel that L1 should be used to maintain discipline and class contro.1 (5\%) think that the student's mother tongue should be used to assign homework and take attendance. Finally, (3\%) think that Arabic should be used to sum up material already covered. For teachers, Arabic was most necessary to explain difficult religious, traditional, cultural and political concepts and ideas $(56 \%)$ and to present and explain complex grammatical rules $(34 \%)$. (30\%) of the teachers think that Arabic should be used to give weak learners a chance to improve and to define some new vocabulary items and this is greater than the students' response. (28\%) think that the students' mother tongue should be used to compare between structures in Arabic and English. (22\%) think that L1 should be used in the EFL classes to discuss students' personal problems outside the classroom. (18\%) think that Arabic should be used in the English classroom to explain the procedure for a task where confusion would result if it was done through English, while only $(2 \%)$ of them believe that it should be used to sum up materials already covered, assign homework, allow students to say what matters to them, prevent the teacher from committing errors in English and take attendance.

Question (3) in the following language skills how much can your students benefit from using Arabic in the English Classroom? 
Table 5. Teachers' and students' opinions on the benefit of Arabic (L1) use in macro-skills.

\begin{tabular}{c|c|c|c|c|c|c|c|c}
\hline & \multicolumn{5}{|c|}{ Teachers \% } & \multicolumn{4}{c}{ Students \% } \\
\hline & listening & Speaking & reading & Writing & listening & Speaking & reading & writing \\
\hline $0-10 \%$ & 38 & 41 & 30 & 25 & 1 & 0 & 2 & 0 \\
\hline $10-40 \%$ & 60 & 59 & 38 & 53 & 55 & 63 & 38 & 34 \\
\hline $40-60 \%$ & 2 & 0 & 26 & 14 & 32 & 27 & 43 & 44 \\
\hline $60-100 \%$ & 0 & 0 & 6 & 8 & 12 & 9 & 17 & 22 \\
\hline
\end{tabular}

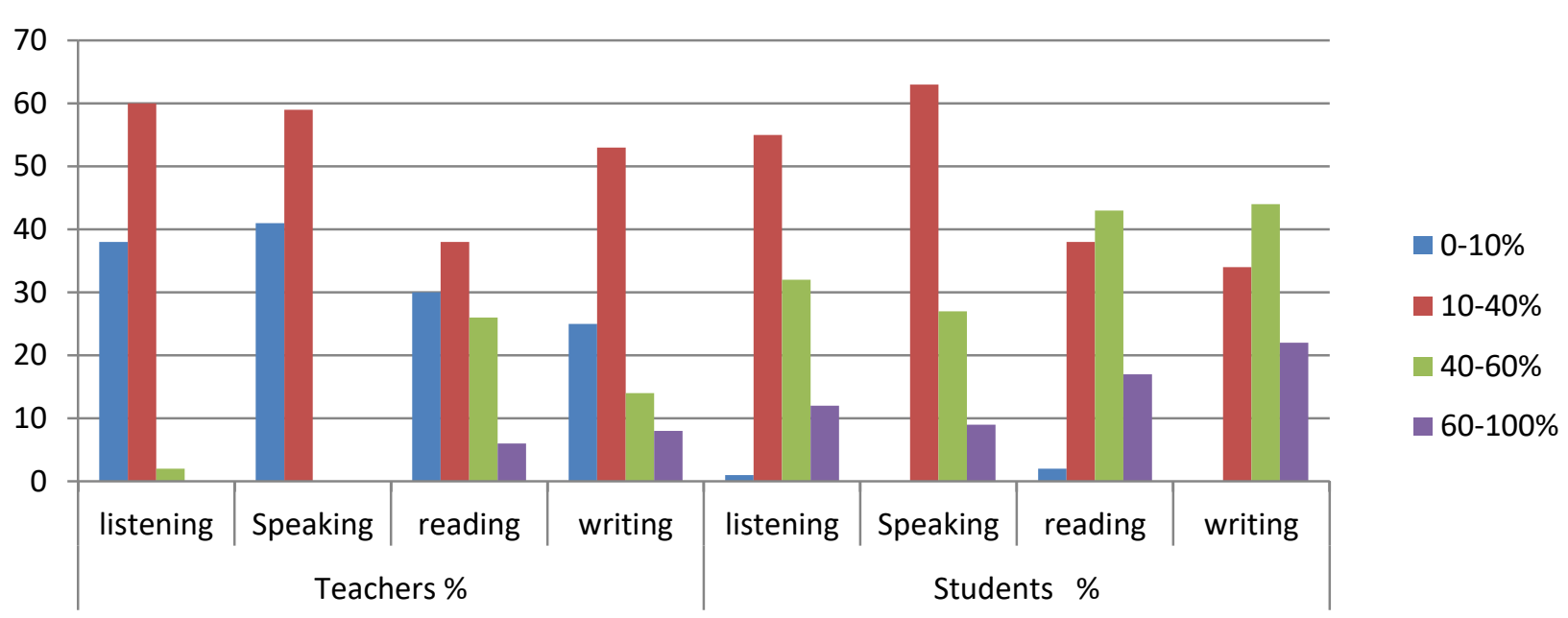

Figure 3. Teachers' and students' opinions on the benefit of Arabic (L1) use in macro-skills

Answers to question (3) in table (5) and figure (3) show the extent to which the respondents think students can benefit by using students' mother tongue in the EFL classroom in each macro-skill. All teachers thought that using the students' mother tongue provided no more than a $40 \%$ benefit for listening and speaking whereas for reading and writing skills, some teachers considered Arabic even useful and beneficial, even though, a 10-40\% benefit was favored. Moreover, the students showed nearly similar opinion to the teachers' in listening and speaking. In those skills, $10-40 \%$ was noted as the maximum benefit for L1 use; however 9\% of the students considered the percent of benefit was higher, $60-100 \%$. For the macro-skill reading and writing, most of the students saw a 40-60\% benefit from the use of Arabic in the EFL classroom. A small number of the students thought using Arabic benefits a 60-100\% in the four macro-skills. Generally speaking, all the participants seemed to agree that there is at least a $10-40 \%$ benefit from using the students' mother tongue language in teaching all macro-skills, with a notably higher benefit in writing and reading.

Question (4) What percentage of time do you think Arabic should be used in the EFL Classrooms?

Table 6. Participants' perspectives of the percentage of the time of using Arabic in the English classroom

\begin{tabular}{c|c|c}
\hline \multirow{2}{*}{ Percentage of Time } & \multicolumn{2}{|c}{ Responses } \\
\cline { 2 - 3 } & Students & Teachers \\
\hline $0 \%$ & $5 \%$ & $26 \%$ \\
\hline $10 \%$ & $43 \%$ & $68 \%$ \\
\hline $20 \%$ & $23 \%$ & $6 \%$ \\
\hline $30 \%$ & $15 \%$ & $0 \%$ \\
\hline $40 \%$ & $7 \%$ & $0 \%$ \\
\hline $50 \%$ & $0 \%$ & $0 \%$ \\
\hline $60 \%$ & $0 \%$ & $0 \%$ \\
\hline $70 \%$ & $0 \%$ & $0 \%$ \\
\hline $80 \%$ & $0 \%$ & $0 \%$ \\
\hline $90 \%$ & $0 \%$ & $0 \%$ \\
\hline
\end{tabular}




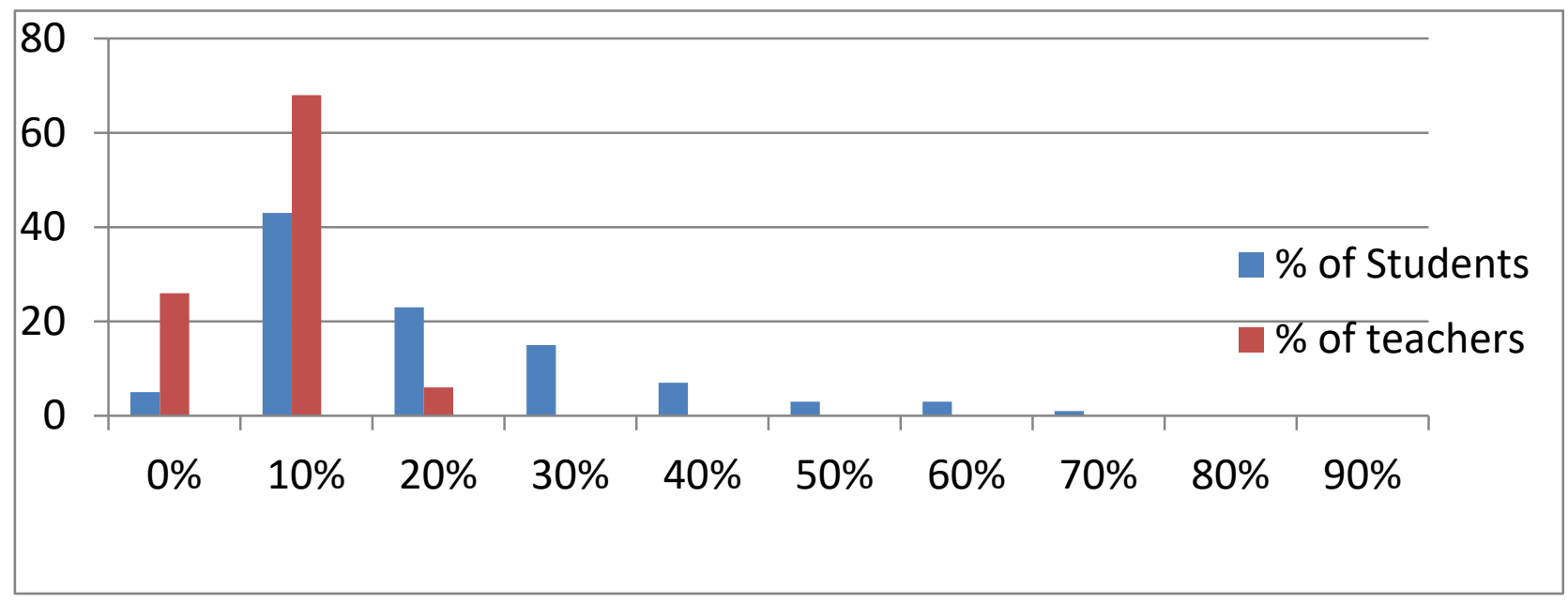

Figure 4. Teachers' and students' attitudes towards acceptable amounts of L1 Use

As can be observed from the responses given in table (6) and figure (4), the quantitative data on the percentage of Arabic that can be used in EFL classroom indicates that most students and teachers prefer only around $10 \%$ use of Arabic in a 50- minute classroom. There are no more teachers who support more than $20 \%$ use of the students' mother tongue. $23 \%$ of the students thought that 20\% students' mother tongue should be used in the EFL classroom, while $6 \%$ of the teachers thought so. Only $7 \%$ of the students replied that $40 \%$ Arabic should be used in an English classroom.

Question (5) To what extent do you think Arabic should be used in the English classroom?

Table 7. Respondents' Perspectives of the Frequency of Using Arabic in an English Classroom

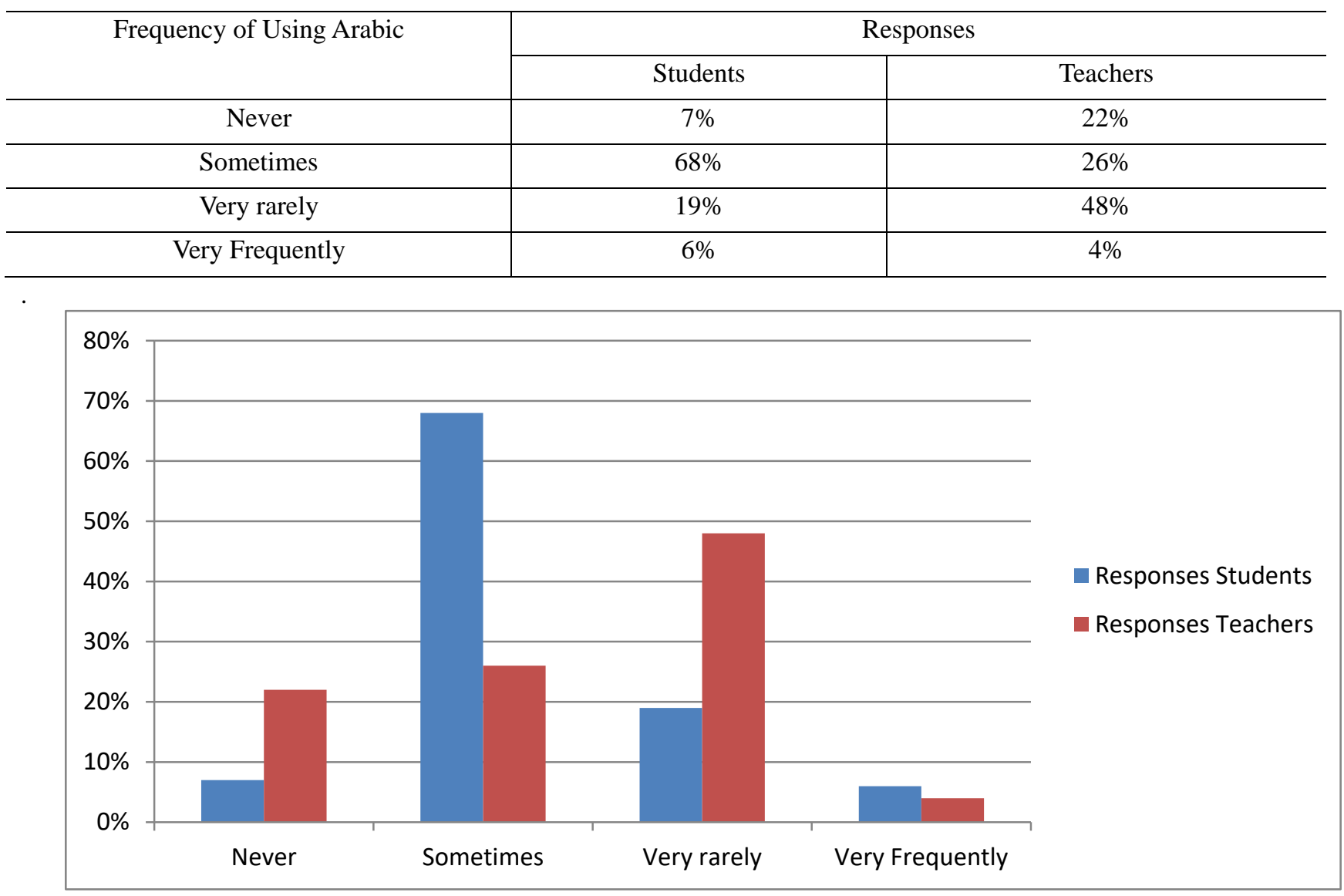

Figure 5. Respondents' perspectives of the frequency of using Arabic in an English classroom 
According to the replies to question 6 in table (7) and figure (5) above, more than half of the students (68\%) thought that Arabic should be used in the EFL classroom "sometimes". Most students do not support the "very frequent" use and "no" use of Arabic in an English classroom (6\% and 7\%) respectively.19\% of the students thought that L1 can be used "very rarely". $48 \%$ of the teachers thought that Arabic can be used "very rarely" ,while $22 \%$ believed and responded it should not be used in the EFL classes. However, only $26 \%$ of the teachers thought it can be used "sometimes". $4 \%$ of the teachers responded it can be used "very frequent"

Question 6. In your opinion, does using Arabic in the English classroom help teachers to teach and students to learn English better?

Table 8. Respondents' perspectives if using Arabic in an English classroom helps teachers and students

\begin{tabular}{c|c|c}
\hline \multirow{2}{*}{ Frequency of Using Arabic } & \multicolumn{2}{|c}{ Responses } \\
\cline { 2 - 3 } & Students & $38 \%$ \\
\hline No & $7 \%$ & $50 \%$ \\
\hline A little & $39 \%$ & $12 \%$ \\
\hline Fairly much & $19 \%$ & $0 \%$ \\
\hline A lot & $35 \%$ & 0 \\
\hline
\end{tabular}

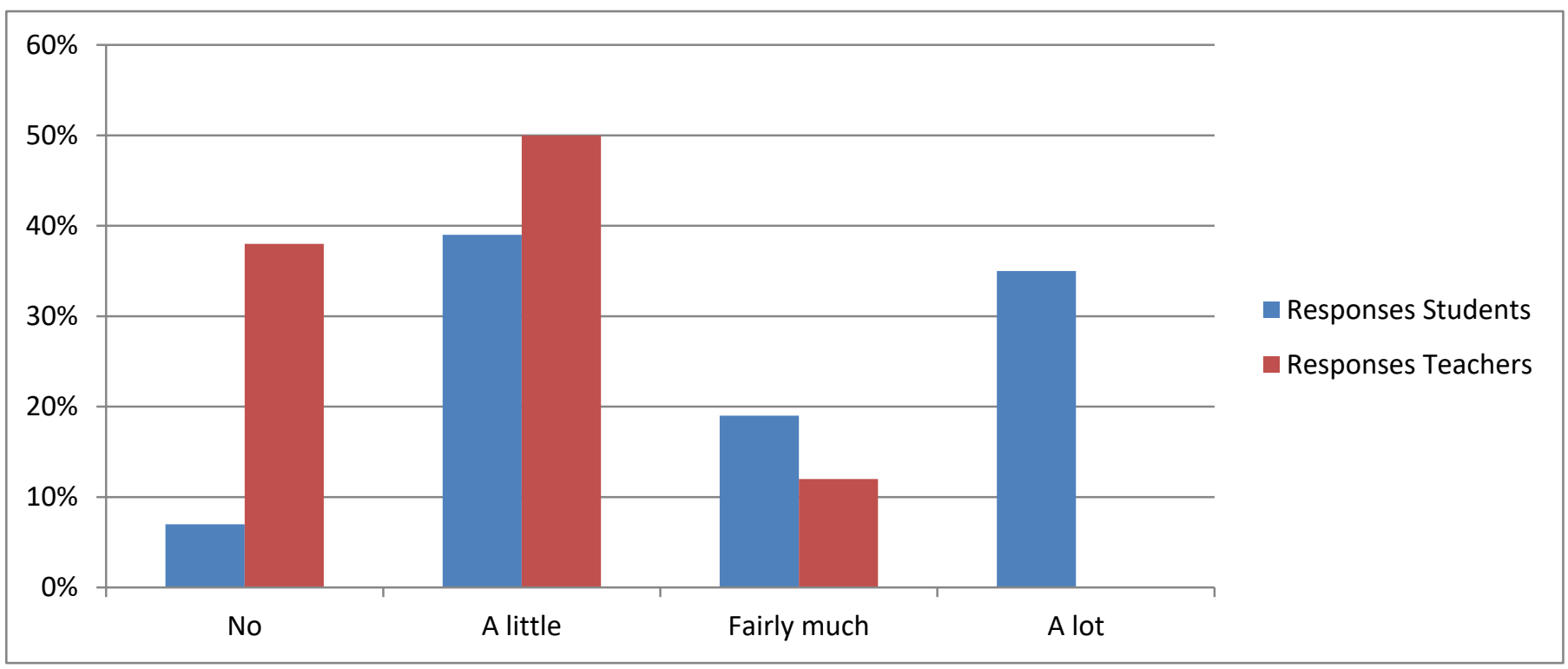

Figure 6. Respondents' perspectives if using Arabic in an English classroom helps teachers and students

As can be seen from table (8) and figure (6) above, half of the teachers (50\%) thought that Arabic helped English learning "a little" , 38\% thought that it did not help English learning at all, 12\% thought it helped "fairly much", and $0 \%$ felt that Arabic helped "a lot". While 39\% of the students felt that L1 helped English learning "a little", 35\% thought that it helped "a lot", 19\% replied that it helped "Fairly much" and 7\% thought that it did not help at all.

Question (7) What are the factors which influence teachers' decisions about using Arabic in the English classroom? (teachers only

Table 9. Influences on teachers' decisions about using L1 (Arabic)

\begin{tabular}{c|c}
\hline Influence & $\%$ \\
\hline Teachers' Experience & $44 \%$ \\
\hline Supervisor/ mentor & $28 \%$ \\
\hline Colleagues & $6 \%$ \\
\hline Time constraints & $14 \%$ \\
\hline Studying at college/ university & $8 \%$ \\
\hline Training sessions & $18 \%$ \\
\hline Finishing the curriculum in a predetermined time & $10 \%$ \\
\hline
\end{tabular}




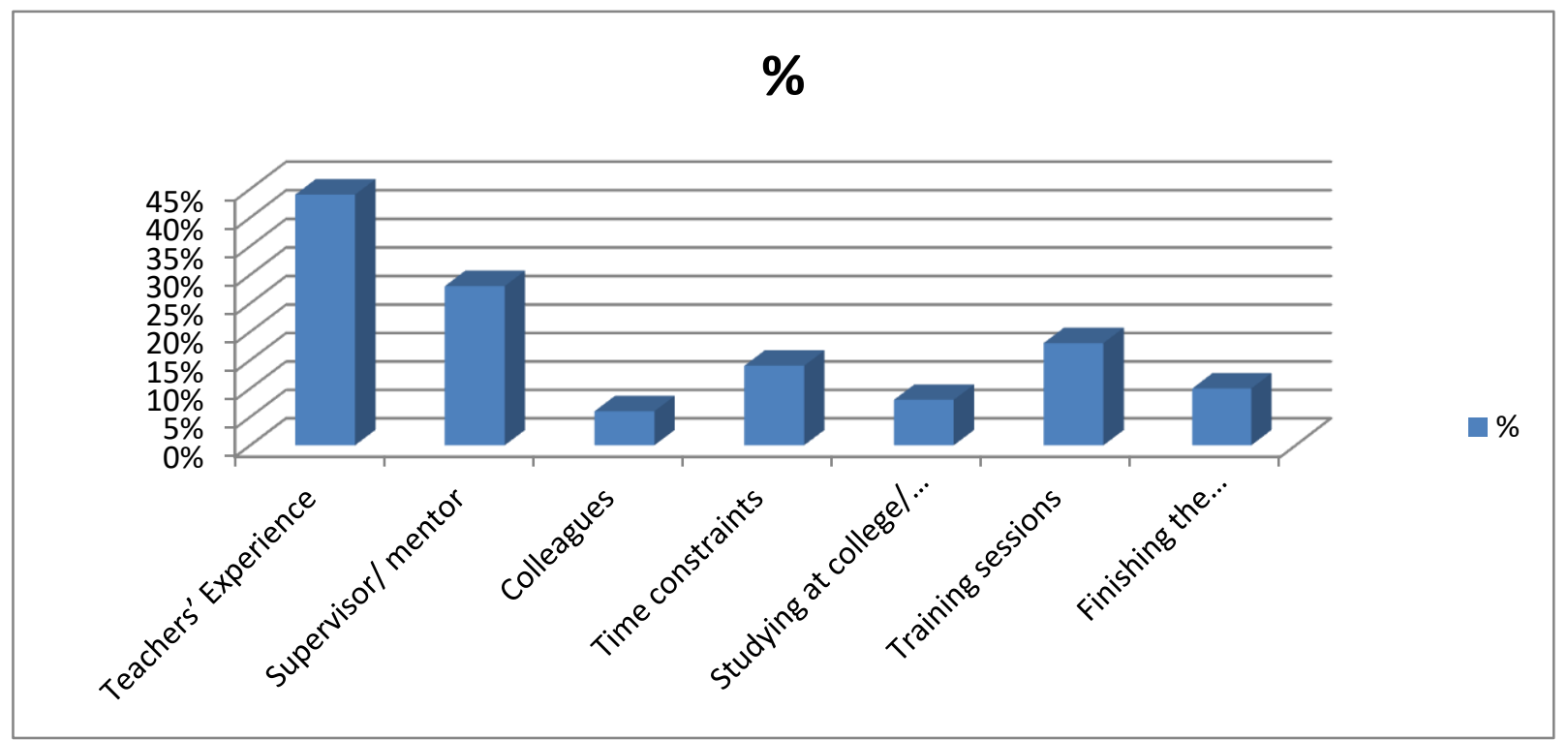

Figure 7. Influences on teachers' decisions about using L1 (Arabic)

Concerning the influences on teachers' beliefs about using Arabic in an English classroom, table (9) and figure (7) indicate that "teachers' experience" had influenced their beliefs about using Arabic in teaching English 44\%. Supervisors or mentors were the influence referred to second most frequently $28 \%$. The remaining influences on the teachers' beliefs were training, time constraints, finishing the curriculum in a predetermined time, studying at college or university and colleagues with varying degrees of responses.

Question (8) Why do you think (L1) Arabic should be used in an English classroom?

Table 10. Respondents' perspectives if Arabic is necessary in an English classroom

\begin{tabular}{|c|c|}
\hline Why Using Arabic is necessary & Students' Responses \% \\
\hline It helps me understand the difficult concepts and ideas better & $52 \%$ \\
\hline It helps me write better reports & $20 \%$ \\
\hline It helps me understand the new grammatical rules and new vocabulary items & $52 \%$ \\
\hline It helps me feel more confident and less confused & $13 \%$ \\
\hline It helps me ask "how do I say---X - in English?" & $46 \%$ \\
\hline It helps me review elements learnt in previous lesson(s) & $5 \%$ \\
\hline Why Using Arabic is necessary & Teachers' Responses\% \\
\hline It helps me establish a rapport with my students & $8 \%$ \\
\hline It helps me save a lot of time and effort & $20 \%$ \\
\hline It aids comprehension greatly & $16 \%$ \\
\hline It helps my students appreciate me as I know their language. & $4 \%$ \\
\hline It helps me know my students learning problems more effectively & $22 \%$ \\
\hline It is more effective & $24 \%$ \\
\hline $\begin{array}{l}\text { It helps me increase my own and my students' awareness about the similarities and } \\
\text { differences between Arabic and English }\end{array}$ & $16 \%$ \\
\hline \multicolumn{2}{|c|}{$\begin{array}{l}\text { In explaining why the subjects think the use of Arabic is necessary in an English classroom, more than half of the } \\
\text { students }(52 \%) \text { thought that it helped them understand the difficult concepts and ideas better as well as it helped them } \\
\text { understand the new grammatical rules and new vocabulary items, followed by ( } 46 \%) \text { who thought that using Arabic in } \\
\text { an English classroom helped them ask "How do I say---X--- in English?" .Only }(5 \%) \text { students replied that it helped } \\
\text { them review elements learnt in the previous lesson. Similarly, } 24 \% \text { of the teachers answered because "it is more }\end{array}$} \\
\hline
\end{tabular}


effective", $22 \%$ replied that it helped them "know their students' learning problems more effectively" and $20 \%$ answered that it helped them "save a lot of time and effort". Other option for why it is necessary to use the students' mother tongue language L1 in an English classroom, some teachers indicated that Arabic could help their students' comprehension greatly as well as it could help them "increase their own and their students' awareness about the differences and similarities between Arabic and English". Only 8\% teachers realized that it helped them establish a rapport with their students when they use Arabic.

The open-ended question: No (9) List as many areas as you want in which Arabic should be used in the English classroom.

In response to the following question "List as many areas as you want in which Arabic can be used in an English classroom", the subjects listed the following areas:-

1- Giving Classroom instructions and directions to the class.

2- Explaining classroom rules, protocols and exam instructions.

3- Translation as a test.

4- Presenting rules of grammar, morphology, phonology and spelling because this enriches the similarities and differences between English and Arabic.

5- Developing wordiness and prolixity strategies: When a student does not know how to say or write a word in English, the teacher may ask him/her to put it in another way to say something in Arabic, which is much easier to translate.

6- Explaining the meanings of the abstract words that are difficult to be explained by pictures or other techniques.

7- Translating answers to low achievers.

8- Checking comprehension of a listening or a reading text.

9- Explaining the topic that the students are going to write about.

10- Solidarity and empathy: When a teacher uses the students' mother tongue language, a sense of closeness with students and a friendly rapport is created.

11- Co-operation among learners: students, in pairs or groups, compare, analyze and correct answers to grammatical exercises, comprehension tasks etc. and other English activities. In this respect, Arabic explanation by a peer who has understood may well succeed.

Question (10) Do you like your teacher to use Arabic in an English classroom? (Students only)

Table 11. Respondents' perspectives toward the amount of time of using Arabic in the English classrooms

\begin{tabular}{c|c}
\hline Responses & $\%$ \\
\hline Not at all & $5 \%$ \\
\hline sometimes & $53 \%$ \\
\hline frequently & $10 \%$ \\
\hline A little & $32 \%$ \\
\hline
\end{tabular}

95\% of the students think that Arabic should be used in the English classroom with different degrees of responses like "a little" (32\%), "sometimes" (53\%), and finally "frequently" (10\%). Almost all the students refuse the excessive use of Arabic (L1) in the English classroom. 


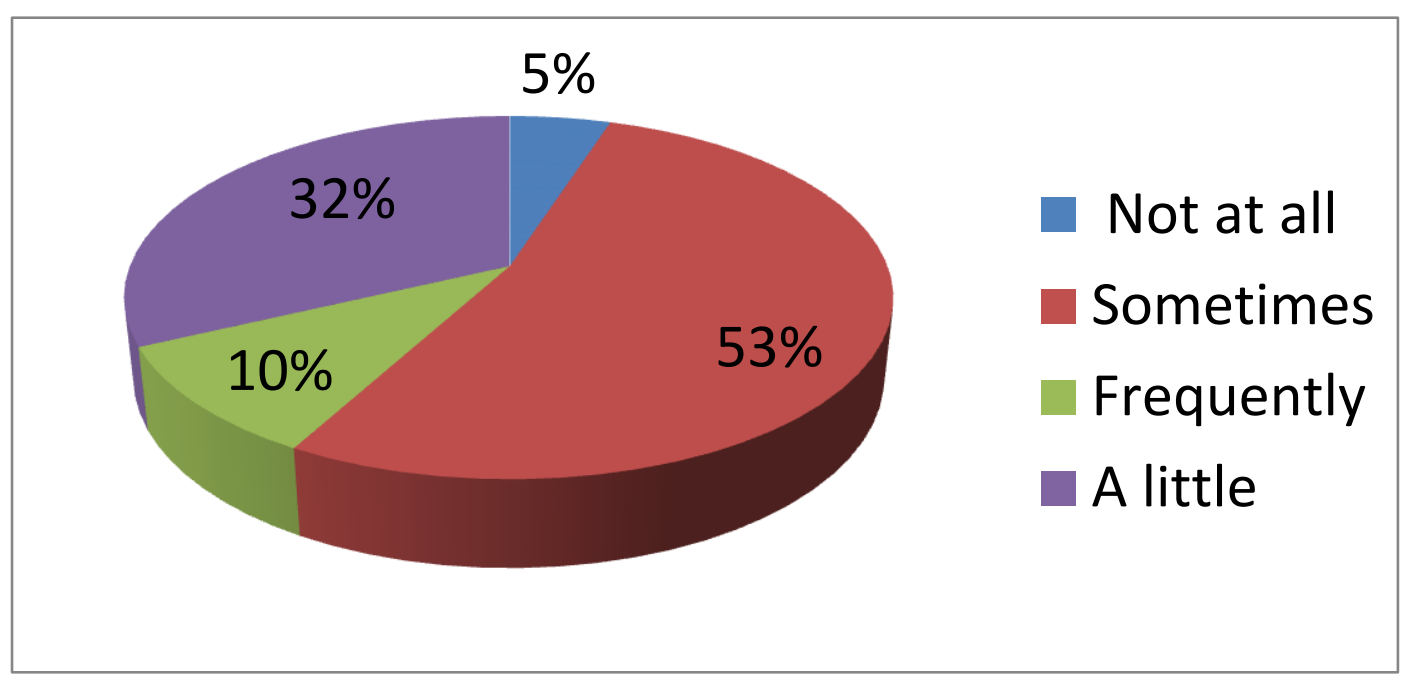

Figure 8. Students' perspectives of the amount of time of using Arabic in EFL classes

Question (10) What do you usually do when your students do not understand what you say in English? (Teachers only).

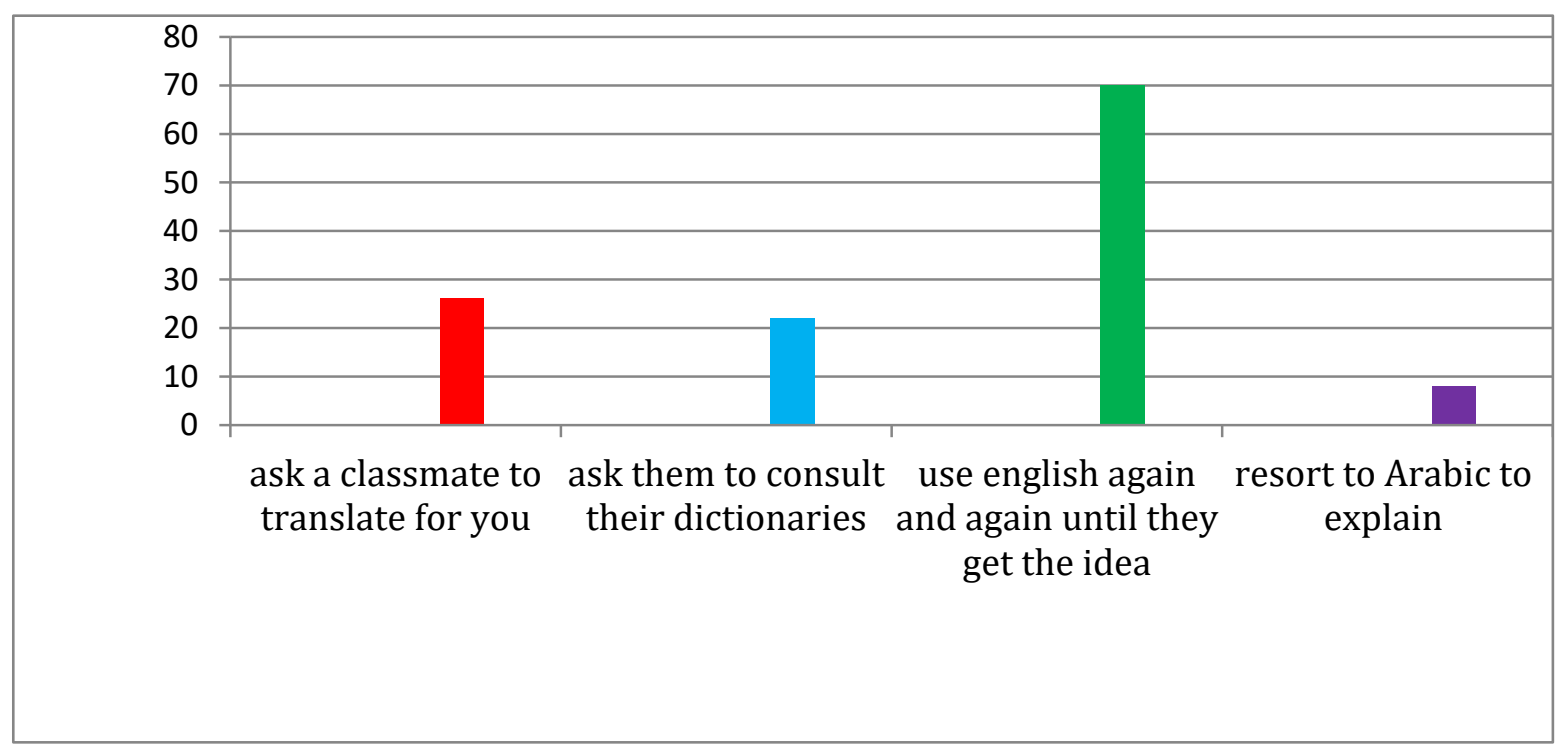

Figure 9. Teachers' strategies to deal with confused words/ideas

When asked about what they usually do when their students do not understand what they say in English, (70\%) of the them replied that they should use English again and again until they get the idea, $(26 \%)$ of the teachers replied that they should ask a classmate to translate for the others, and $22 \%$ of the teachers replied that they ask the students to use their dictionaries. But (8\%) would resort to Arabic to explain it.

\subsection{Discussions}

In spite of the literature and studies (Turnbull 2001, Atkinson 1987, Kharma and Hajjaj 1989, Macdonald, 1993 and Sharma, 2006) that discuss the disadvantages of using L1 in an English classroom, there is complete agreement and evidence among teachers and students about the use and benefit of L1 in an English classroom, despite the fact that students wanted more L1 use than teachers. The results of this study on teachers' and students' attitudes towards using Arabic in an English classroom were almost similar to (Dolye's 1997, Schweers' 1999, William's 1999, Tang's 2002, and Al-Makhzoomi and Ahmed's 2005). All these studies showed that the students' mother tongue should be used by both teachers and students and had positive attitudes towards its use. Minor differences were found related to the occasions and purposes when the students' mother tongue language should be used. Some of these differences in the participants' responses were resulted from the students' level of proficiency.

The results of this study showed that $72 \%$ of the students and $54 \%$ of their teachers felt that Arabic should be used in 
their English classroom. Most of the participants said that difficult religious, traditional, cultural and political concepts should be taught in an English classroom by referring to the students' mother tongue. In almost all the situations of using Arabic in an English classroom, students responded notably higher than their teachers on almost all the items in the questionnaire. 68\% students preferred using Arabic in their English classroom "sometimes". This percentage was closely similar to Tang's 2002, but higher than Al-Makhzoomi and Ahmed's 2005 and Sharma's 2006. More than half of the students agreed that using the student's first language (Arabic) whenever necessary helped them understand the difficult concepts and better ideas as well as the new grammatical rules and new vocabulary items more effectively. This study also showed that in an English classroom L1 plays "a supportive and facilitating role" (Tang, 2002, P.41) although English should be "the primary vehicle of communication" Schweers, 1999 (cited in Kim and Petraki 2009). Although some of the students said that English language was imposed on them or considered it as a threat to their identity, especially when teaching traditional, cultural and religious issues as well as abstract words. This, in turn, increases the students' hatred to English as a foreign language.

A wide range of reasons for which teachers and students used Arabic in an English classroom were identified; the most commonly cited reasons were:

- Explaining difficult religious, traditional, cultural and political concepts and issues.

- Helping students feel more comfortable, confident and less stressed.

- Expressing things which are difficult to say in English.

- Explaining complex grammatical rules and abstract words.

- Giving instructions for tasks and exams.

- Comparing between structures in Arabic and English.

- Giving weak learners a chance to improve.

These findings are in harmony with Schweers' 1999, Al-Makhzoomi and Ahmed's 2005, Sharma's 2006 and Al-Hadrami's 2008).

This study also supports Tang's findings that "limited and judicious use of the mother tongue in an English classroom does not reduce or decrease the students' exposure to English, but rather can assist in the teaching and learning processes" (2002: P.41). The study also reveals that the complete prohibition of using mother tongue in an English classroom will certainly hinder the students from certain opportunities to learn more and better. Teachers should be very selective on when to use Arabic in an English classroom and when not to use.

According to the data obtained from the questionnaire again, both teachers and students deemed $10 \%$ class time use of Arabic language appropriate.

\section{Conclusions, Pedagogical Implications \& Recommendations}

\subsection{Conclusions}

This study was in harmony with other studies which concentrate on the importance of using the students' mother tongue language and its effect on understanding L2 (English) (Mukattash, 1986; Kharma,1987; Kharma and Hajjaj, 1989; Hamdallah, 1990; Mahmoud, 2003; Al-Makhzoomi and Ahmed, 2005).To those who claimed that English classes are the only media through which students practice their English with their teachers, I can say that there are other media in which students can practice English: face book, Internet, radio, T.V, Twitter and computer. Using the students' mother tongue language in an English classroom to save time and effort for both the teachers and the students is not an effective technique for Emirati students. This does not mean that L1 has no place in an English classroom. Our students bring with them complete comprehension of their mother tongue language which they will surely draw upon in the process of acquiring a second language. Using the students' mother tongue language to raise their awareness about the differences and similarities between L1 (in our case is Arabic) and English can be a powerful and efficient technique in the learning process.

\subsection{Pedagogical Implications \&Recommendations}

Based on the above conclusions, the following recommendations are important steps that schools can adapt to improve the teaching environment and secure students' success

First, teachers, English textbooks designers and administrators should work closely together towards the improvement of the curriculum and the teaching strategies by providing students with material that covers translation exercises from English into Arabic and vice versa. 
Second, in EFL classrooms there is a need to refer to Arabic to compare and contrast some religious and cultural concepts. (Makhzoomi \& Ahmed 2005) Using the students' native language in the EFL classroom helps students to raise their awareness and knowledge about the similarities and differences between the two languages, and helps them to discover different methods to practice and to express themselves in the target language.

Third, effective collaboration between non-native English Speaking Teachers (Arabic native speakers) and native English Speaking Teachers can also work towards this goal by increasing their opportunities for language practice and updating their English Language skills.

Fourth, students of the Month Award. A rewarding system should be implemented where rewards are granted to students who try to use and communicate in English. The points are counted at the end of the month and those who accumulate the most grant a reward, which motivate students to do likewise.

Fifth, researchers could also conduct a study on the L1 use in the first cycle students since they tend to acquire foreign languages in a similar way to the acquisition of their mother tongue.

Sixth, multilingual language classrooms in private schools are worth investigating, in particular how the students' approach to L1 differs from students with the same background.

Seventh, furthermore, a study could also look at the relationship between teachers' practices in using the L1 and learners' proficiency.

Eighth, teachers should be aware of when, how and why to use L1, that is to say, the suitable use of L1.

Ninth, the study finds out that the complete prohibition of the use of L1 in English classes will indeed debar the students from certain opportunities to learn more and better.

Tenth, in EFL classrooms, using the students' mother tongue language to raise students' awareness about their similarities and differences between L1 and L2 and helping them to discover different ways to express themselves in the target language can be an effective strategy in the learning-teaching process, a strategy that should not be abandoned so fast.

Eleventh, for low Level achievers (those who are not proficient enough in English), Arabic can be sometimes used as a facilitating tool.

Twelfth, It is also recommended that the Ministry of Education ought to hold seminars, workshops on the role of the learners' native language in the EFL classrooms and strategies to improve students' motivation and efficiency by combining Arabic with English when necessary.

Thirteenth, further research can be conducted to investigate the effect of the use of the native language on reading, writing, grammar and vocabulary separately.

Fourteenth, it is recommended to conduct a study on another sample to investigate the use of the learners' native language (L1) to teach reading, grammar, writing and vocabulary separately, especially at beginning stages of learning.

Fifteenth, it is recommended to carry out a study to show the effect of gender, teachers' qualifications on EFL teachers' attitudes towards using (L1) in the EFL classroom.

Sixteenth, creating an "English atmosphere." The English -speaking atmosphere helps the students think in the target language. For example, the researcher tries to make more situations in which the students are obliged to speak in English, for example, inviting a native speaker of English to the classroom to tell them a story about an important event in his life, then let the students ask some questions.

In conclusion, the researcher has found that evidence for the practice of English-only is neither conclusive nor pedagogically sound (Auerbach, 1993, p.15). In fact, it is often detrimental to the students and the learning process (Chaudron, in Polio, 1994, p.159). (Auerbach, 1993, p.9, Hawks, 2001, p.51 and Zhou, 2003, p.50) show that the use of L1 in the EFL classes can be effective, and perhaps necessary in certain situations.

"Although the mother tongue is not a suitable basis for a methodology, it has, at all levels, a variety of roles to play which are at present, consistently undervalued." (Atkinson, 1987, p.247 cited in Miles, 2004).

It is hoped that these results and findings will help to make more people acknowledge of the L1 in the L2 classrooms and stimulate more studies in this area. 


\section{References}

Al- Nofaie, H. (2010). The Attitudes of Teachers and Students towards Using Arabic in the EFL Classrooms in Saudi Public Schools: A Case Study, in Novitas -Royal (Research on Youth and Language), 4(1), 64-95.

Al-Alawi, T. M. (2008). Teachers'Beliefs and Practices about the Use of (L1) .In S. Borg (Ed.) .Investigating English Language Teaching and Learning in Oman, Muscat: Ministry of Education, Oman.

Al-Buraiki, M. A. (2008). The (L1) in the Young Learner Classroom: Teachers' Views and Practices. Retrieved June 19, 2010 from www.moe.Gov.om/Portal/sites/ESP/English/MOE/.../ Ch2.pdf

Al-Hadrami, A. H. (2008). The Role of the L1 in Grade 5 EFL Classrooms. In S.Borg(Ed). Investigation English Language Teaching and Learning in Oman .Muscat: Ministry of Education, Oman.

Al-Qadumi, H. A. (2007). Teachers' Attitudes toward Using the Mother Tongue in the EFL Classroom. Al-Quds University Journal for Research and Studies, 10, 1-31.

Al-Shidhani, A. N. (2009). Teachers' Beliefs about Using Arabic in the English Classroom. In S. Borg (Ed.) .Investigating English Language Teaching and Learning in Oman, Muscat: Ministry of Education, Oman.

Anton, M., \& Di Camilla, F. J. (1998). Socio-cognitive Functions of L1 Collaboration Interaction in the L2 Classroom. Canadian Modern Language Review, 54(3), 314-342. https://doi.org/10.3138/cmlr.54.3.314

Atkinson, D. (1987). The Mother Tongue in the Classroom: a neglected resource? ELT Journal, 41(4), $241-247$. https://doi.org/10.1093/elt/41.4.241

Auerbach, E. R. (1993). Re-examining English Only in the Classroom. TESOL Quarterly, 27(1), 9-32. https://doi.org/10.2307/3586949

Balosa, D. (2007). Three examples of Better English Learning through the L1. Retrieved March 2007. Available at http:// fesolorg /s_tesol/secetdoc.asp?

Beressa, K. (2003). Using L1 in the EFL Classroom: The Case of the Oromo Language with Particular Reference to Adama Teachers College. Unpublished M.A Dissertation, Addis Ababa University. School of Graduate Studies. (On line) Available:

http://etd.aau.edu.et/dspace/bitstream/123456789/3071/1/3370478457/10655099214088755732563872552 (August 20. 2012).

Bolitho, R. (1983). Talking Shop: the Communicative Teaching of English in Non-English-Speaking Countries .English Language Teaching Journal, 37(3), 235-242. https://doi.org/10.1093/elt/37.3.235

Buckmaster, R. (2000). First and Second Languages do Battle for the Classroom. Retrieved from: http://education.guardian.coUk/print/O,3858,4032401,00.html

Buckmaster, R. (2002). Using L1: What King of Sin? Retrieved June, 16, 2010 from: http://iatefl.org.pl/nletter18/nlet 18-2htm, 2002.

Butzkamm, W. (2003). We Only Learn Language Once. The Role of the Mother Tongue in FT Classrooms: death of a dogma. Language Learning Journal, 28(1), 29-39. https://doi.org/10.1080/09571730385200181

Cameron, L. (2001). Teaching Languages to Young Learners. Cambridge: Cambridge university press. https://doi.org/10.1017/CBO9780511733109

Carless, D. (2008). Student Use of the Mother Tongue in the Task-Based Classroom. ELT Journal, 62(4), $331-338$. https://doi.org/10.1093/elt/ccm090

Chavez, M. (2002). The Diglossic Foreign -Language Class: Learners' Views on L1 and L2 Functions. In C. Blyth (Ed.), The Sociolinguistics of Foreign Language Classrooms: AA USC issues in language program direction. Boston: Heinle and Heinle, 163-208.

Choffey, S. (2001). The L1 Culture in the L2 Classroom. Modern English Teacher, 10(2), 54-58.

Cole, S. (1998). The Use of L1 in Communicative English Classrooms. The Language Teacher. Online, http://www.jalt-publications.Org/tlt/files/98/dec/cole.html

Cook, V. (2001). Using the First Language in the Classroom. Canadian Modern Language Review, 57(3), $402-423$. https://doi.org/10.3138/cmlr.57.3.402

Cook, V. (2001b). Using the Language in the Classroom. http://www.utpjournals.com/jour-ihtml?1p=cmlr/573?573-coc(June15,2006). 2007 from http://www.teachingenglish.org.uk/think/methodology/mothertongue.shtml 
Critchley, M. P. (2002). The Role of (L1) Support in Communicative EFL: A Guide for Teachers in Japan. The Language Teacher, 23(9):1-9. Retrieved June 15, 2010 from http://wwww.encounters.jp/mike/professional/.../JALT2002reduced.pdf

Dajani, D. (2002). Using Mother Tongue to Become a Better Learner: Why and How. Modern English Teacher, 11(2), 65-67.

Deller, S. (2003). The Language of the Learner. English Teaching Professional, 26.

Doyle, T. (1997). The L1's Role in ESL Instruction. Paper Presented at TESOL 97, In Orlando, FL.

Duff, P. A., \& Polio, C. G. (1990). How Much Foreign Language is There in the Foreign Language Classroom? Modern Language Journal, 74, 154-166. https://doi.org/10.1111/j.1540-4781.1990.tb02561.x

Echevarria, J., \& Graves, A. (1998). Sheltered Content Instruction: Teaching English-Language Learners with Diverse Abilities. Boston: Allyn and Bacon.

Ellis, R. (1985). Understanding Second Language Acquisition. Oxford: Oxford University Press.

Ellis, R. (1994). The Study of Second Language Acquisition. Oxford: Oxford University Press.

Ellis, R. (2005). Principles of instructed Language Learning. Asian EFL Journal, 7(3).

Frankenberg-Garcia, A. (2000) Using Portuguese in the Teaching of English. On-line Internet. Available: http://www.Portuguesemct.pt/Repositorio/Frankenburg-Garcia2000b.doc

Freeman. L. D. (2000) .Techniques and Principles in Language Teaching. New York: Oxford University Press.

Gill, S. (2005). The L1 in the L2 Classroom. Retrieved on May22, 2008 from:

Hamdallah, R. (1990). Syntactic Errors in Written English: Study of Errors Made by Arab Students of English. PhD Dissertation Abstract, University of Lancaster, U.K.

Hamdallah. (1999). To Use or Not to Use Arabic in English Language Teaching. An Najah National University Research Journal-B, 13(1):285-296.

Harbord, J. (1992). The Use of the Mother Tongue in the Classroom. EFL Journal, 46(4), 350-355.

Harmer, J. (2001). The Practice of English Language Teaching. England: Pearson Education Limited.

Hawks, P. (2001). Making Distinctions: a discussion of the use of the mother tongue I $n$ the foreign language classroom. Retrieved from:

Hinai, M. K. (2006). The Use of the (L1) in the Elementary Classroom. In S. Borg (ED.) Classroom Research in English Language Teaching in Oman. Muscat: Ministry of Education, Sultanate of Oman.

Hopkins, S. (1988). Use of the Mother Tongue in the Teaching of English as a Second Language to Adults. Language Issues, 2(2), 18-24.

Hopkins, S. (1989). Use of Mother Tongue in Teaching of English as a Second Language to Adults. Language Issues, 2(2), 18-24.

Howatt, A. (1984). A History of English Language Teaching .Oxford: OUP.

http:// WWW.asian-efl jornal.com/june_2003_PN. Php.

http://geocities.com/collegePark/classroom/1930/Journal/May2001/page9.html

http://stat can .ca/English/pgdb/people/ population/demo3ba.htm

http://WWW.hltmag.co.uk/Sp/05/mart03.htm

Jadallah, M., \& Fuad, H. (2010). A Review of Some New Trends in Using (L1) in the EFL Classroom. Retrieved September 12, 2011, from www.qou.edu/english/ conferences/ first national conference/.../ dr.Mufeed. Pdf

Janulevicien, V and Kavaliauskien, G. (2002). Promoting the Fifth Skill in Teaching SP. ESP World, 1(2) (on line) http://www.Espworld.info/articles_2/promoting\%20the\%20fifth\%20skill\%20in\%20teaching\%20Esp.html7,(access ed June 2006).

Kharma, N. (1987). Arab Students' Problems with the English Relative Clauses. IRAL, 25(3), 257-266.

Kharma, N. N., \& Hajjaj, A. H. (1989). Use of the Mother Tongue in the ESL Classroom. IRAL, 27(3), 223-235.

Kim Anh, K. H. (2010). Use of Vietnamese in English Language Teaching in Vietnam: Attitudes of Vietnamese University Teachers. English Language Teaching, 3(2), 119-128. 
Kim, Y., \& E. Petraki. (2009). Students' and Teachers' Use of and Attitudes to L1 in the EFL Classroom. Asian EFL Journal, 11(4), 58-89.

Kramsch, C. (1993). Context and Culture in Language Teaching. Oxford: Oxford University Press.

Langer, S. L. (2001). The Effect of Home Language Use in the ESL Classroom: Additive or Subtractive? On-line Internet. Available A; the effect of home language use in the ESL classroom.5_langer.htm

Larsen-Freeman, D. (2000). Techniques and Principles in Language Teaching . $2^{\text {nd }}$ ed. Oxford: Oxford University Press.

Macaro, E. (2005). Code switching in the (L2) Classroom: A Communication and Learning Strategy. In E. L1 urda(ed.) Non-Native Language Teachers: Perceptions, Challenges and Contributions of the Profession (PP.63-83) New York: Springer.

Macdonald, C. (1993). Using the Target Language. Cheltenhman: Mary Glasgow.

Mahmoud, A. (2003). The relative Effect of a Pragmatic Approach on Improving the Comprehension and Translation Skills of the Advanced -Level- Program Students In Amman Private Schools. An Unpublished PhD Dissertation, Amman, Jordan.

Makhzoomi, K., \& Ahmed A. A. (2005). The Use of Arabic in Classes of English as a Foreign Language. Jordan Journal of Educational Sciences, 1(2), 149-153.

Miles, R. (2004). Evaluating the Use of L1 in the English Language Classroom. School of Humanities. Centre for English Language Studies Department of English. University of Birmingham.

Mukattash, L. (1984). Contrastive Analysis and the Adult EFL Learner. World Language English, 3, 178-181. https://doi.org/10.1111/j.1467-971X.1984.tb00602.x

Mukattash, L. (1986). Persistence of Fossilization. IRAL, 24(3), 187-203. https://doi.org/10.1515/iral.1986.24.1-4.187

Murakami, I. (1999). The Bridging Strategy: Active Use of the Learners' First Language in Second Language Teaching. On-line Internet. Available: http:// www.htmag.Co.Uk/novol/martnov013.rtf

Nation, I. S. P. (1990). A System of Tasks for Language Learning .In Anvivan (Ed.), Language Teaching Methodology for Nineties. RELC Anthology Series, 24, 51-63.

Nation, P. (2003). The Role of the First Language in Foreign Language Learning .Asian EFL Journal, 5(2) .Retrieved 10 September 2007 from

Nazary, M. (2008). The Role of L1 in L2 Acquisition: attitudes of Iranian University students, Novitas-Royal, 2(2), 138-153. Retrieved 14 March 2010 from: http://novitasroyal.org./Nazary.Pdf

Nazary, M. M. (2008). EFL Stuttering Students: the role of the teacher and the classroom. Manuscript submitted for publication.

Nunan, D., \& Lamb, C. (1996). The Self-Directed Teacher. Cambridge: Cambridge University Press.

Phillipson, R. (1992). Linguistic Imperialism. Oxford: Oxford University Press.

Piasecka, K. (1988). The Bilingual Teacher in the ESL Classroom. In.S. Nicholls and E.Hoadley-Maidment (Eds.), Current Issues in Teaching English as a Second Language to Adults. Pp. (79-103) .London: Edward Arnold.

Polio, C. (1994). Comments on Elsa Roberts Auerbach's "Re-examining English Only in the ESL Classroom. TESOL Quarterly, 28(1), 153-161. https://doi.org/10.2307/3587203

Polio, C., \& Duff, P. (1994). Teachers' Language Use in University Foreign Language Classroom: a Qualitative Analysis of English and Target Language Alteration. The Modern Language Journal, 78(3), 313-326. https://doi.org/10.1111/j.1540-4781.1994.tb02045.x

Prodromou (2002). From Mother Tongue to Other Tongue: What is the Place of the Learners' Mother Tongue in the EFL Classroom? Retrieved on August 20.

Prodromou, L. (2001) From Mother Tongue to other Tongue. Bridges, 5.

Py, B. (1996). Reflection, Conceptualization and Exo linguistic Interaction: Observations on the Role of the First Language. Language Awareness: 179-187.

Qadri, T. A. (2006). Teachers' and Students' Practices and Attitudes toward Arabic (L1) use in ELT. Unpublished M.A thesis. The American University of Sharjah, UAE.

Reis, L. A. P. (1996). The Myths and the Practical Needs of Using L1 in the EFL Classes: A Learner Training Experiment. English Teaching Forum, 34(4), 61-62. Retrieved April 12, 2005, from http:// www.asian - 
efl-journal.com/September_o5_re.php

Rinvolucri, M. (2001). Mother Tongue in the Foreign Classroom. Modern Language Teacher. 10(2), 41-44.

Robinson, P. (2001). Task Complexity, Task Difficulty, and Task Production: Exploring Interactions in a Componential Frame. Applied Linguistics, 22(1), 27-57. https://doi.org/10.1093/applin/22.1.27

Schweers, C. W. (1999). Using L1 in the L2 Classroom? (WWW) http://exchanges.state.gov/forum/vols/vol37/no2/p.6htm (February3.2005)

Sharma, K. (2006). Mother Tongue Use in English Classroom. In Journal of NELTA, 11(1-2), 80-87.

Shimizu,M.(2006). Monolingual or Bilingual Policy in the Classroom: bPedagogical Implications of (L1) Use in the Japanese EFL Classroom. Maebashi kyoai GakuenCollege Ronsyu, 6(2), 75-89. Retrieved July31,2010from http://wwww.kyoai.ac.jp/college/ronshuu/no-o6/shimizu.pdf

Stern, H. H. (1992) .Issues and Options in Language Teaching. Oxford: Oxford University Press: 279

Storch, N., \& Aldosari, A. (2010). Learners' Use of (L1) Arabic in Pair Work Activity in an EFL Class. Language Teaching Research, 14, 355-376. https://doi.org/10.1177/1362168810375362

Storch, N., \& Wigglesworth, G. (2003). Is There a Role for the Use of L1 in an L2 Setting? TESOL Quarterly, 37(4), 760-770. https://doi.org/10.2307/3588224

Swain, M., \& S. Lapkin. (2000). Task-Based Second Language Learning: The Uses of the First Language. Language Teaching Research, 4(3), 251-274. https://doi.org/10.1177/136216880000400304

Tang,J. (2002). Using L1 in the English Classroom. In English Teaching Forum, 40(1), 36-43.

Tsui, A. B. M. (1996). Reticence and Anxiety in Second Language Learning. In K. Bailey and D.Nunan (eds) Voices from the Language Classroom. Cambridge: Cambridge University Press.

Turnbull, M. (2001). There is a Role for the L1 in the Second and Foreign Language Teaching, but-1. Canadian Modern Language Review, 57(4), 531-540. https://doi.org/10.3138/cmlr.57.4.531

Tushyeh, H. Y. (1990). The English Language Teaching Situation in the West Bank. Jerusalem: The AMIDEAST.

Urgese, T. (1987). L1 as a useful Tool in Teaching Foreign Languages. English Teaching Forum, 25(3), 39-40.

William, C. (1999) .The use of L1 in L2 Classes. English Teaching Forum, 37(2), 6-13.

Willis, J. (1981). Teaching English Through English. Harlow: Longman.

Zhou, J. (2003). New Wine in an Old Bottle: Innovative EFL Classrooms in China. IATEFL Issues April-May 2003.

\section{Copyrights}

Copyright for this article is retained by the author(s), with first publication rights granted to the journal.

This is an open-access article distributed under the terms and conditions of the Creative Commons Attribution license which permits unrestricted use, distribution, and reproduction in any medium, provided the original work is properly cited. 